\title{
Zakat Mal dalam Perspektii Hadis Maudhu'iy
}

\author{
Hamzah \\ Dosen Jurusan Syariah Sekolah Tinggi Agama Islam Negeri \\ Sorong Papua Barat \\ hamzahkhaeriyah@yahoo.co.id
}

Abstract: One of the major problems that the developing countries face is the lack of state revenues to cover all required expenses. Zakat is completely different from taxes, because it is a direct solution for poor people because it goes with the same type of property from the rich to the poor (not like the most of the poverty reduction programms which go in shape of projects for the poor), also Zakat has its own fixed resources and fixed legal channels of spending. Zakat is considered a form of charity that must be paid from a person's wealth (when his/her wealth exceeds or reaches a "specific amount" of money (or othertypes of wealth like gold) So when the wealth reaches this level or (the specific amount) the person who owns this wealth should pay a specific amount for the poor and this amount goes to the poor named Zakat. At the time of prophet Mohamed, he was sending the officials to collect money of Zakat, as it was mentioned for example, when he sent Muaaz Ibnu Jabal to govern Yemen, he ordered him to collect money of Zakat. Also in the time of the second gonernant in Islam (Khalifah). At the time of the third Khalifah Umar, where the state was expanded, Umar still interested in collecting Zakat but with a new way in terms of two perspectives, first collecting it from both outward and inward money, second by establishing "a Zakat organization" to be the 
ideal solution in dealing with Zakat. At the time of umar the revenues of Zakat became a huge amount, until Umar decided to give a salary for The periods after that the governants were not interested so much to collect Zakat by themselves and from the outward and inward money, because total toll became very huge so they decided to leave this mater up to the eligible Muslims to pay their Zakat, but in the later on periods of time the Muslims became less aware by the religious practises so the total toll of Zakat became less than periods of the prophet and Khalifah and not sufficient to satisfy the basic needs of the poor in the Muslim countries. To conclude from that, the best total yield of Zakat was happened when it was collected and distributed through an organization with a great attention from the leader of the state, so this paper will be describe about zakat persepective Hadis Maudu' in the first time of Islam.

Keywords: Zakat, Hadist Maudu' and Ummah.

\section{Pendahuluan}

Islam merupakan risalah atau ajaran yang disampaikan Allah swt. kepada Nabi Muhammad saw. sebagai petunjuk bagi seluruh manusia. Secara tegas Islam memberikan perhatian yang lebih besar kepada pencapaian kebahagiaan hidup manusia di dunia. Hal ini tergambar pada lima macam kemaslahatan dasar bagi manusia, yang dirumuskan dalam "al-kulliyat al-khams" di antaranya adalah kemaslahatan jiwa raga manusia $(a l-n a f s)^{1}$. Zakat merupakan jenis ibadah yang memiliki arti penting dalam ajaran Islam, dan ia terkait dengan kesejahteraan umat. Zakat ini termasuk ibadah pokok, karena merupakan rukun Islam ketiga dalam Islam. Dengan demikian, mereka yang mampu dari segi ekonomi, namun enggang mengeluarkan zakat berarti belum menunaikan salah satu ajaran pokok dalam Islam.

1 Empat yang lainnya adalah : (1) urusan agama, (2) urusan akal, (3) urusan keturunan, dan (4) urusan harta milik, lihat: TM, Hasbi ash-Shiddiqiey, Falsafah Hukum Islam, (Jakarta: Bulan Bintang, 1990), h. 188. 
Demikian pentingnya zakat dalam ajaran Islam, sehingga di dalam al-Qur'an terdapat 27 ayat yang menyejajarkan kewajiban shalat dengan kewajiban zakat dalam berbagai bentuk kata. ${ }^{2}$ Di dalam al-Qur'an terdapat pula berbagai ayat yang memuji orang-orang yang secara sungguhsungguh menunaikannya, ${ }^{3}$ dan sebaliknya memberikan ancaman bagi orang yang sengaja mengabaikannya. ${ }^{4}$ Di samping al-Qur'an, di dalam hadis pun banyak ditemukan tema-tema yang berkenaan dengan zakat. Bahkan penjelasan tentang zakat dalam hadis sangat jelas dan terperinci. Zakat yang dijelaskan dalam al-Qur'an dan demikian dalam hadis, terdiri atas dua, zakat fitrah dan zakat mal. Jenis zakat yang pertama, diwajibkan pada bulan Ramadhan, terutama menjelang Idul Fitri. Jenis zakat yang kedua diwajibkan bukan saja di bulan Ramadhan, dan dalam hal ini selama seseorang memiliki harta dan nishab (jumlah)nya sudah cukup menurut ketentuan agama, wajib dikeluarkan, inilah yang dimaksud zakat mal dan dibebankan kepada ketiap muslim baik di bulan ramadhan maupun di luar bulan Ramadhan.

Al-Qur'an dalam menyebutkan term zakat mal, kadang menggunakan term al-zakat dan derivasinya, dan kadang pula menggunakan term al-shadaqah. Allah swt. berfirman dalam QS. Al-Taubah (9): 103

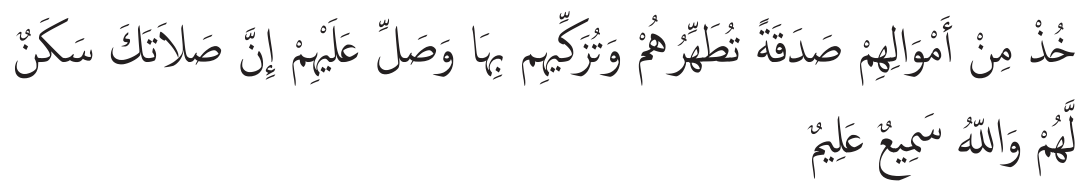

Artinya:

Ambillah zakat dari sebagian harta mereka, dengan zakat itu kamu membersihkan dan mensucikan mereka dan berdoalah untuk mereka. Sesungguhnya doa kamu itu (menjadi) ketenteraman jiwa bagi mereka. dan Allah Maha mendengar lagi Maha Mengetahui. ${ }^{5}$

2 Lihat Muhammad Fu'ad Abd al-Baqy, Al-Mu'jam al-Mufahras Li Alfazh al-Qur'an al-Karim (Bairut: Dar al-Fikr, 1992), h. 420.

3 Lihat QS. al-Taubah (9): 11.

4 Lihat QS. al-Taubah (9): 34-35.

5 Departemen Agama RI, Al-Qur'an dan Terjemahnya (Jakarta: Proyek Pengadaan 
M. Quraish Shihab menjelaskan bahwa term " أموالمم "dalam ayat di atas yang berarti "harta mereka" mengindikasikan bahwa zakat berkaitan langsung dengan "mal", dan term "صدقة" yang secara literal berarti sedekah di dalam ayat tersebut diartikan "zakat mal" yang berfungsi untuk membersihkan manusia dari dosa sebagaimana yang dipahami dalam term "طهر هـ ". Dari sini kemudian dipahami bahwa term zakat mang juga digunakan dalam beberapa redaksi hadis kadang dengan term "shadaqah". Demikian halnya sama dengan Al-Qur'an, di dalam hadis banyak menyebutkan bahwa zakat berfungsi untuk membersihkan harta manusia, dan masih banyak lagi fungsi zakat yang disebutkan dalam hadis-hadis. Fungsi zakat yang lain misalnya yang disebutkan dalam hadis, adalah sebagai sarana pengentasan kemiskinan. Yang demikian ini dijelaskan oleh Arifuddin Ahmad dalam bukunya Paradigma Baru Memahami Hadis Nabi bahwa upaya mengatasi kemiskinan adalah "peranan dan kepedulian orang-orang kaya dalam melaksanakan ketentuan zakat, sangatlah penting".

Dalam upaya mengelaborasi hadis-hadis tentang zakat mal, tentu saja sangat penting bila hadis-hadis tersebut dikaji dengan pendekatan metode maudhui'y. Sebab, dengan metode seperti ini, akan diketahui bagaimana konsep zakat mal itu sebagai salah satu rukun Islam yang sangat signifikan. Untuk kajian lebih lanjut berikut, maka masalah pokok tulisan ini adalah:

1. Bagaimana pengertian zakat harta?

2. Bagaimana redaksi hadis, takhrij, dan kualitas hadis-hadis tentang kewajiban zakat mal

3. Berapa nishab dan haul zakat mal menurut hadis?

Kitab Suci Al-Qur'an, 1992), h. 297-298.

6 M. Quraish Shihab, Tafsir al-Mishbah; Pesan, Kesan dan Keserasian Al-Qur'an, (Jakarta: Lentera Hati, 2006), h. 709.

7 Arifuddin Ahmad, Paradigma Baru Memahami Hadis Nabi; Refleksi Pemikiran Prof. Dr. M. Syuhudi Ismail, (Jakarti: Renaisan, 2005), h. 229. 


\section{Pengertian Zakat Harta}

Zakat dari segi literalnya berasal dari bahasa Arab, terdiri atas huruf za (j), ka (s), dan wa (و). Yang terakhir ini, adalah dinamai huruf mu'tal dan karena ia sulit dilafazkan, maka cukup dibaca zakat (aك), ia terganti dengan huruf ta al-marbuthah. Secara etimologi kata zakat berarti berkah, tumbuh, bersih, baik dan bertambah. ${ }^{8}$ Makna lain dari zakat ialah suci dari dosa. Zakat juga diartikan suci, tumbuh dan berkembang. Dalam Islam apabila harta itu dizakati, maka harta tersebut akan berkembang dan bertambah, karena suci dan mendapat berkah. Oleh karena itu zakat dapat dirumuskan sebagai bagian dari harta yang wajib diberikan oleh setiap muslim yang memenuhi syarat kepada orang-orang tertentu dengan syarat-syarat tertentu pula. ${ }^{9}$ Menurut M. Quraish Shihab zakat juga bisa berarti suci. Sebab pengeluaran harta bila dilakukan dalam keadaan ikhlas dan sesuai dengan tuntunan agama, dapat menyucikan harta dan jiwa yang mengeluarkannya. ${ }^{10}$ Dengan demikian, makna linguistik yang terkandung dalam term zakat adalah pengembangan harta dan pensuciannya, sekaligus mensucikan diri orang yang berzakat.

Dalam kamus al-Wasith disebutkan bahwa zakat secara terminologi ialah bagian dari harta dan sejenisnya yang wajib dibagikan kepada orang-orang fakir dan yang dikelompokkan dengan mereka dengan syarat-syarat tertentu. ${ }^{11}$ Sedangkan Yusuf al-Qardhawi mendefinisikan bahwa, Zakat dari segi istilah fikih adalah sejumlah harta tertentu yang diwajibkan Allah diserahkan kepada orang-orang yang berhak, di samping berarti mengeluarkan jumlah tertentu itu sendiri. Jumlah yang

8 Abdul Aziz Dahlan, (et al), Ensiklopedi Islam Jilid 5, (Jakarta: Ichtiar Baru Van Hoeve, th. 1994), h. 224. bandingkan dengan A.W. Munawwir, Kamus al-Munawwir Arab-Indonesia, (Surabaya: Pustaka Progressif, th. 1997.

9 Lihat Moh. Daud Ali, Sistem Ekonomi Islam, Zakat, dan Wakaf, (Jakarta UI Press, th. 1998), h. 38-39

${ }^{10}$ M. Quraish Shihab, Fatwa-fatwa Seputar Ibadah Mahdah (Cet. I; Bandung: Mizan, 1999), h. 158.

${ }^{11}$ Ibrahim Musthafa Ahmad Husain al-Ziyat, Mu'jam al-Wasith, Juz I; (Istambul: Al-Maktabah al-Islamiyah, th. 1972), h. 396-397. 
dikeluarkan dari kekayaan itu disebut zakat karena yang dikeluarkan itu menambah banyak, membuat lebih berarti. ${ }^{12}$

Dari pengertian diatas, setidaknya ada empat hal yang melekat pada makna zakat, yaitu: Pertama, adanya harta tertentu yang wajib dikeluarkan oleh orang Islam. Kedua, adanya golongan yang berhak sebagai penerima zakat. Kelompok yang dikenal mustahiq ini secara jelas disebutkan oleh Allah swt. dalam al-Qur'an pada surah al-Taubah (9) ayat 60. Ketiga, adanya aturan khusus tentang pengelolaan zakat yang diatur oleh syariah. Keempat, adanya tujuan yang hendak dicapai dalam mengeluarkan zakat yaitu mensucikan dan membersihkan jiwa dan harta yang mengeluarkan, sehingga yang bersangkutan selalu mendapatkan ridha di sisi Allah swt.

Sedangkan mal atau harta mempunyai nilai yang sangat strategis, karena ia merupakan alat dan sarana untuk memperoleh berbagai manfaat dan mencapai kesejahteraan hidup menusia sepanjang waktu. ${ }^{13}$ Dalam al-Qur'an terdapat 82 kata harta (المال). Jika dilihat dari bentuk katanya sebagian besar dalam bentuk jamak dengan menggunakan khitab mutakallim ma'a al-gair atau dhamir jama' muzakkar seperti (أموالىم ) sebanyak 14 kali, (أموالمم), sebanyak 31 kali, dan (مالى) sebanyak 15 kali. ${ }^{14} \mathrm{Hal}$ ini menunjukkan bahwa harta benda merupakan milik bersama (public goods), meskipun harta tersebut dimiliki perorangan. Dengan kata lain, harta itu berfungsi sosial. Dalam kajian fiqh, pembahasan tentang harta benda tersebar dalam berbagai bidang, termasuk

${ }^{12}$ Yusuf al-Qardhawi, Fiqh al-Zakat diterjemahkan oleh Salman Harun, Didin Hafidhuddin, dan Hasanuddin dengan Hukum Zakat (Jakarta: Pustaka Lentera AntarNusa, 1996), h. 34.

${ }^{13}$ Abi Ubaid Qosim bin Salam, Kitab Amwal, (Dar al-Fikr, Cairo, 1975), h.17

${ }^{14}$ Lafaz amwalukum terdapat dalam surah al-Baqarah ayat 188, 297; Ali Imran: 186; al-Nisa: 5, 29; al-Anfal: 28; al-Taubah: 42; Muhammad: 39; al-Shaf: 11; Tagabun: 15; Saba: 37; al-Munafiqun: 9; Sedangkan lafaz amwaluhum terdapat pada surah alBaqarah: 262, 264, 274; Ali Imran: 10, 116, 186; al-Nisa: 2, 6, 34, 38, 95; al-Anfal: 36, 72; al-Taubah: 21, 45, 82, 86, 104, 112; Yunus: 88; Al-Ahzab: 27; al-Hujurat: 15; al-Dzariyat: 19; al-mujadilah: 17; al-Hasyr: 8; al-Ma'arij: 24. Lihat Muhammad Fuad 'Abd al-Baqi, al-Mu'jam Mufahras li alfaz al-Qur'an al-Karim, (Jakarta: Angkasa, 1982), h. 682-683 
dalam bidang munakahat dan bidang ahwal al-syakhsyiah, serta muamalat. ${ }^{15}$

Dalam definisi Sayyid Sabiq bahwa zakat mal adalah zakat atas harta yang wajib dikeluarkan oleh setiap muslim apabila telah sampai nishab/haulnya. Harta-harta yang wajib dizakati itu terdiri dari harta peternakan, harta emas dan perak, harta hasil perniagaan, dan harta hasil pertanian, dan termasuk harta hasil pendapatan profesi. ${ }^{16}$ Didin Hafidhuddin dalam mengutip beberapa pendapat ulama, menyatakan bahwa mal yang jamaknya amwal, pada mulanya hanya dibatasi pada perak dan emas, karena inilah harta benda yang paling bermaafaat, namun kemudian berkembang pengertiannya menjadi segala harta benda dan barang yang memungkinkan diperjualbelikan dan menghasilkan uang. ${ }^{17}$ Dari sini kemudian dipahami bahwa yang mal adalah harta yang dapat diperjualbelikan yang sifatnya material, kongkrit, dan memiliki nilai dalam pandangan manusia. Dari definisi-definisi dan penjelasan yang telah dikemukakan, maka dapat dirumuskan bahwa zakat mal adalah harta kekayaan yang wajib dikeluarkan berupa hasilhasil usaha yang halal, baik usaha itu jasa maupun berupa buah-buahan, binatang ternak, kekayaan uang, emas, perak dan kekayaan produksi bumi, bila telah cukup nishabnya.

Selanjutnya mengenai fungsi zakat mal terkait dengan bahasan tentang fungsi harta dalam ajaran agama Islam. Harta yang diperoleh dari hasil usaha manusia bukanlah menjadi milik mutlak baginya. Sebab, di situ terdapat hak manusia lainnya (hak penerima zakat). Karena itu, harta bukan milik mutlak seseorang.

Fungsi harta dalam hukum Islam, dapat dikatakan bahwa dalam kesejahteraan individu terdapat kesejahteraan masyarakat dan di dalam

\footnotetext{
${ }^{15}$ Abdurrahman Qadir, Zakat (Dalam Dimensi Mahdhah dan Sosial), (Jakarta: Raja Grafindo Persada, 1998), h. 5-6

${ }^{16}$ Sayyid Sabiq, Fiqh al-Sunnah, jilid III (Bairut: Dār al-Kitāb al-'Arabiya, 1987), h. 24.

${ }^{17}$ Didin Hafidhuddin, Zakat dalam Perekonomian Modern (Jakarta: Gema Insani Press, 2002), h. 16.
} 
kesejahteraan masyarakat terdapat kesejahteraan individu. Kesejahteraan individu dan kesejahteraan masyarakat bersama-sama menghendaki supaya nafsu dan jiwa (hati nurani) terhadap keseimbangan dan keselarasan yang sehat. ${ }^{18}$ Dengan demikian, akan terjamin kesejahteraan individu di satu pihak dan kesejahteraan masyarakat di lain pihak. Di sini menunjukkan bahwa pemilik harta berkawajiban untuk memberikan hak masyarakat sebagai hak sosial.

Setiap pemilik harta yang memenuhi kriteria wajib zakat, ia harus mengetahui bahwa di dalam hartanya itu terdapat hak milik individu dengan hak milik masyarakat, sehingga dapat memisahkan antara hak pribadinya dengan hak masyarakat. Oleh karena itu, riba, monopoli, pemerasan dan lain sebagainya dilarang oleh Pencipta manusia. Sebab, dapat menggangu kesejahteraan umum atau membawa kemelaratan umum. Hal ini berarti apabila terjadi pertentangan antara kepentingan umum dengan kepentingan pribadi dan tidak mungkin diadakan keseimbangan di antara keduanya, maka hukum Islam mendahulukan kepentingan umum atau kepentingan orang banyak dari pada kepentingan pribadi atau kepentingan individu.

Selain itu, perlu ditegaskan kembali bahwa status hukum Zakat merupakan ibadah wajib yang termasuk rukun Islam yang ke tiga. Sebagai rukun Islam, zakat biasa pula dianggap bukti sistem ekonomi yang dimiliki Islam dan terkait dengan masalah sosial. Itulah sebabnya sehingga zakat merupakan kewajiban yang harus ditunaikan. Selain itu, zakat bukanlah derma atau sedekah biasa, ia adalah iuran wajib yang harus diberikan kepada penerima zakat. Hal ini berarti bahwa pemberian orang-orang kaya kepada orang-orang fakir dan miskin serta penerima zakat lainya, bukanlah belas kasihan, melainkan pelaksanaan kewajiban terhadapnya.

Di samping itu, kedudukan zakat sebagai ibadah wajib kepada Allah, ia akan mencerminkan hubungan manusia sebagai hamba, dan Tuhan sebagai pencipta yang menetapkan kewajiban zakat terhadap

${ }^{18}$ Abu 'A'la al-Maududi, Dasar-dasar Ekonomi Islam “terjemahan” oleh Abdul.ah Suhaili (Bandung: al-Ma’arif, 1980), h. 14. 
orang yang memiliki harta kekayaan. Di sini akan mencerminkan nilainilai keislaman bagi orang yang memiliki kewajiban untuk menunaikan zakat, sekaligus mencerminkan ketakwaannya kepada Tuhan. Zakat merupakan salah satu tolok ukur dalam mengetahui tingkat ketakwaan seseorang. Di samping itu, ia juga berfungsi kemasyarakatan.

\section{Takhrij dan Kualitas Hadis-Hadis tentang Zakat Mal}

Dalam upaya menemukan hadis-hadis zakat mal, maka perlu dilakukan kegiatan takhrij hadis. ${ }^{19}$ Kegiatan ini membutuhkan alat bantu berupa Mu'jam hadis (kamus hadis). Karena hadis yang dicari adalah tentang zakat harta, maka di dalam kamus tersebut ditelusuri kata zakat $(\text { ( ), })^{20}$ dan bisa juga kata shadaqah (الصدقة (ال) sebab sebagaimana yang telah disinggung kata shadaqah ini bisa juga berarti zakat. Namun untuk efektifnya ditelusuri kata mal (مال) atau amwal (أموال) yang artinya "harta" karena bila kata yang terakhir ini digunakan dipastikan bahwa hadis tersebut adalah tentang zakat mal. Artinya bahwa semua kata zakat atau shaqadah dalam Mu'jam bila digandengkan dengan kata mal atau amwal, maka ia adalah hadis tentang zakat mal. Tetapi bilamana kata zakat menyendiri, tanpa ada kata mal atau amwal yang mendahului atau mengakhirinya, boleh jadi hadis tersebut tentang zakat fitrah.

Berdasar pada masalah yang dikaji dan dengan menelusuri kata mal beserta derivasinya dalam $M u^{\prime} j a m$ maka ditemukan informasi bahwa hadis tentang kewajiban zakat mal petunjuknya adalah:

${ }^{19}$ Takhrij hadis adalah pencarian hadis sampai menemukannya dalam berbagai kitab hadis yang disusun langsung oleh mukharrij-nya. Dalam kitab-kitab tersebut disebutkan hadis secara lengkap dari segi sanad dan matan. M. Syuhudi Ismail, Metodologi Penelitian Hadis (Jakarta: Bulan Bintang, 1992), h 43.

${ }^{20}$ Arnold John Wensinck, et al, Concordance et Indices De Ela Tradition Musulmanne, diterjemahkan ke dalam bahasa Arab oleh Muhammad Fu'ad 'Abd. al-Baqy dengan judul al-Mu'jam al-Mufahras Li Alfazh al-Hadits al-Nabawy, juz II (Leiden: E. J.Brill, 1936), h. 338-341.

${ }^{21}$ Ibid., juz III, h. 383-385. 
22 maksudnya "Apabila engkau telah mengeluarkan zakat hartamu maka engkau telah melaksanakan kewajibanmu, ... hadis ini terdapat dalam Sunan alTurmuzi kitab zakat bab ke-5, terdapat juga dalam Sunan Ibn Majah kitab zakat bab ke-17. Petunjuk lain tentang kewajiban zakat adalah:

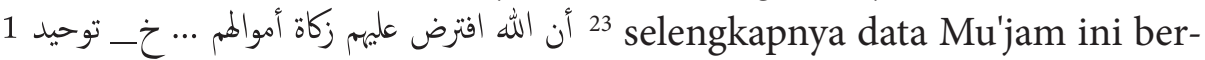
زكاة أموالهم تؤخذ من أغنيائهم فترد فى فقرائه (zakat harta mereka diambil dari orang kaya di antara mereka lalu diberikan kepada orang-orang fakir di antara mereka). Hadis ini sekaligus memberi informasi tentang muzakki adalah orang kaya, dan mustahiq adalah orang fakir. Hadis yang demikian sesuai petunjuk dalam CD. Rom Hadis terdapat dalam (1) Shahih Bukhari kitab zakat hadis ke-138; (2) Shahih Muslim kitab iman hadis ke-27; (3) Sunan al-Turmuzi kitab zakat hadis ke-567; (3) Sunan al-Nasai kitab zakat hadis ke-2392; (4) Sunan Abu Dawud kitab zakat hadis ke-1351; (5) Sunan Ibn Majah kitab zakat hadis ke-1773; (6) Musnad Ahmad, Musnad Baniy Hasyim hadis ke-1967; (7) Sunan al-Darimiy kitab zakat hadis ke-1563. ${ }^{24}$ Selanjutnya hadis tentang nishab dan haul zakat adalah 5 maksudnya, "tidak ada zakat harta mal hingga lewat batasnya satu tahun"... hadis ini terdapat dalam Sunan al-Turmuzi kitab zakat bab 5, dan Sunan Abu Dawud kitab zakat bab ke-5. Berikut ini, dikutip hadis-hadis tersebut secara lengkap sesuai petunjuk Mu'jam dan petunjuk CD. Rom hadis.

Hadis tentang kewajiban zakat mal

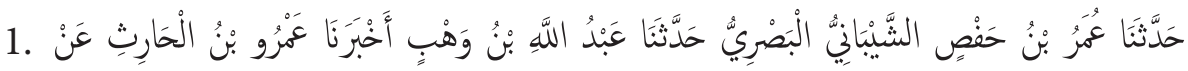

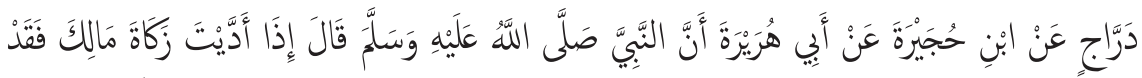

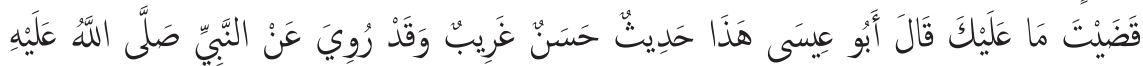

${ }^{22}$ Ibid., juz VI, h. 316

${ }^{23}$ Ibid.

${ }^{24}$ CD. Rom Hadis, dalam Barnabij al-Hadis al-Syarifah al-Kutub al-Tis'ah, program Bahtsul kalimah "iftaradhah"...

${ }^{25}$ Arnold John Wensinck, op. cit., h. 309 


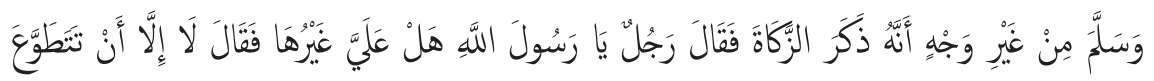

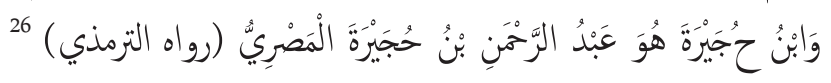

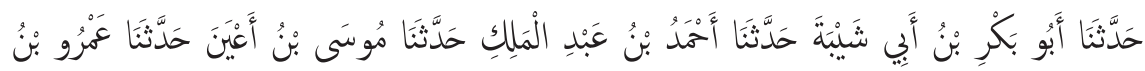

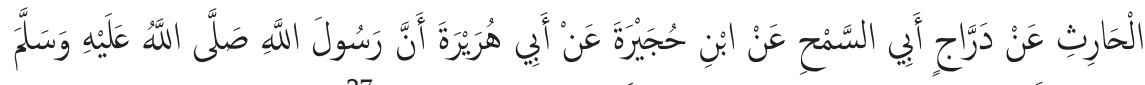

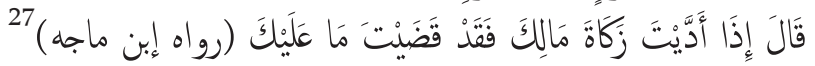

\section{Hadis tentang muzakkiy dan mustahiq zakat mal}

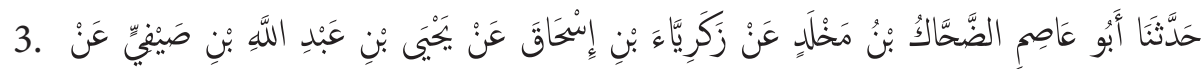

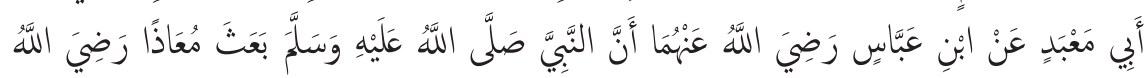

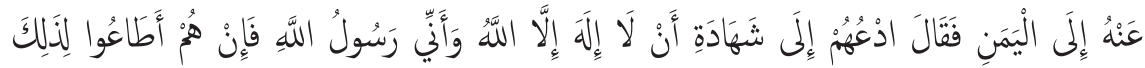

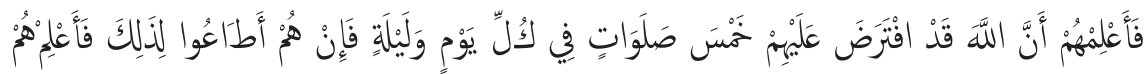

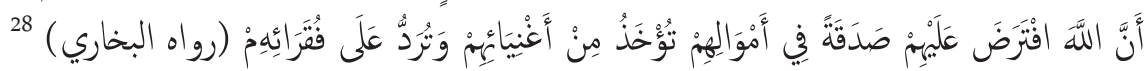

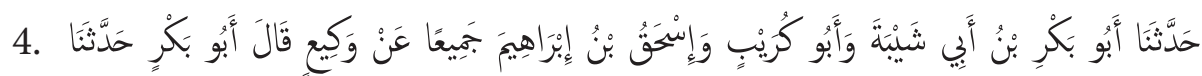

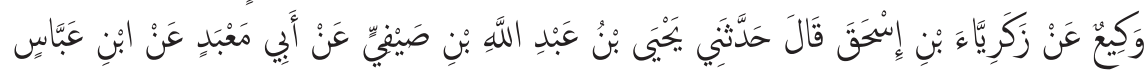

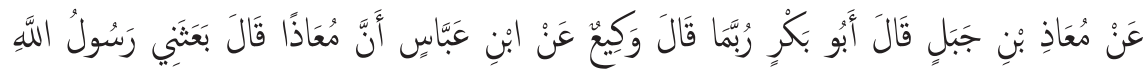

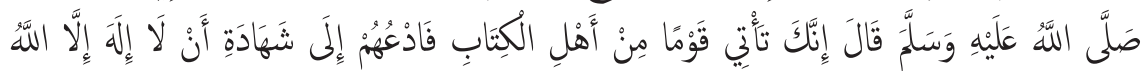

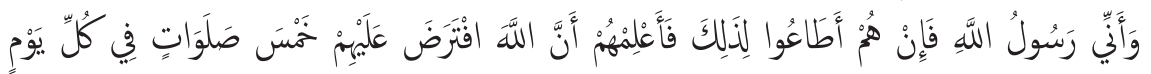

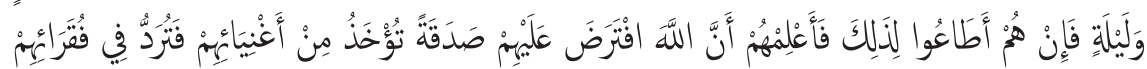

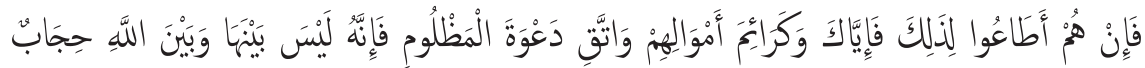

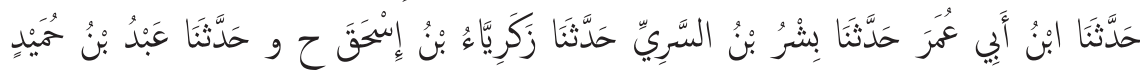

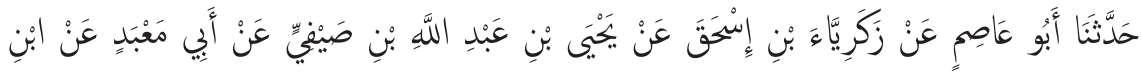

${ }^{26}$ Abu Isa Muhammad ibn Isa ibn Sawrah al-Turmuziy, Sunan al-Turmuziy, dalam kitab al-Zakat, hadis ke-561.

${ }^{27}$ Abdullah Muhammad bin Yazid Ibn Majah, Sunan Ibn Majah, dalam kitab al-Zakat, hadis ke-1778.

${ }^{28} \mathrm{Abu}$ Abdullah Muhammad bin Ismail bin al-Mughirah bin al-Bardizbah al-Bukhari, Shahih Bukhari dalam kitab al-zakat hadis ke-138. 


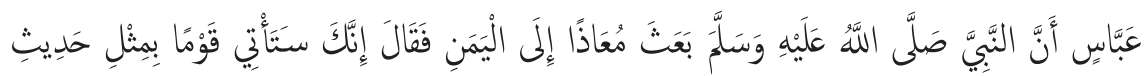

$$
\text { وَكِيعٍِ (رواه مسلم) }
$$

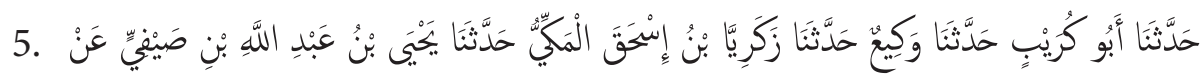

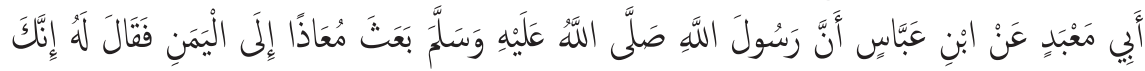

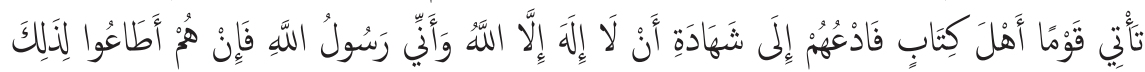

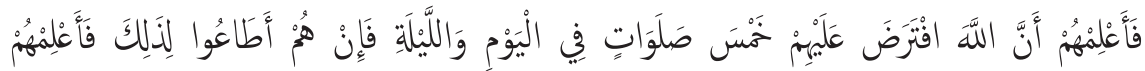

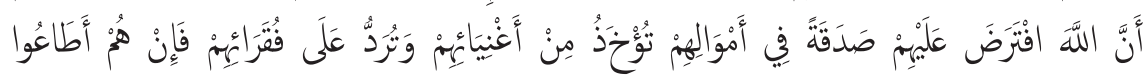

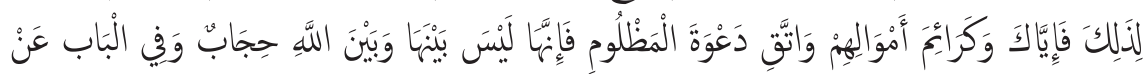

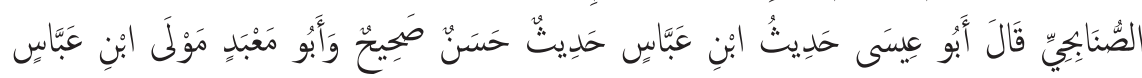

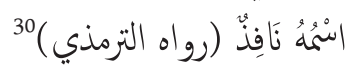

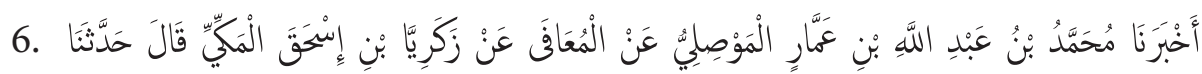

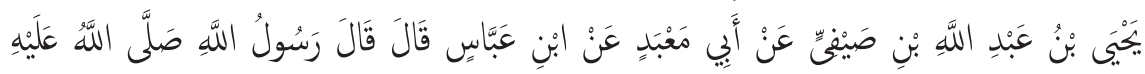

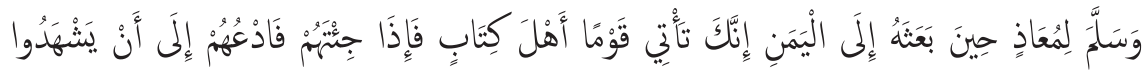

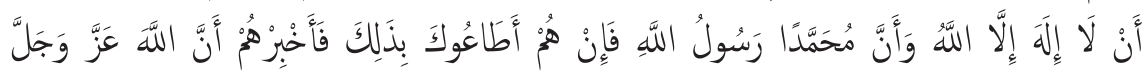

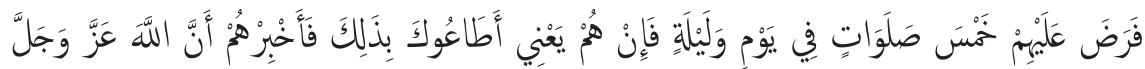

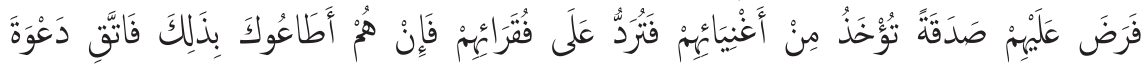

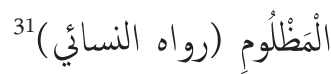

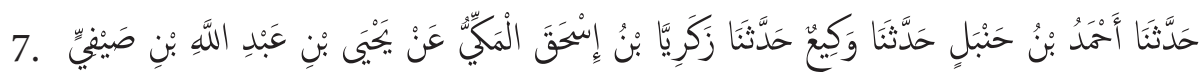

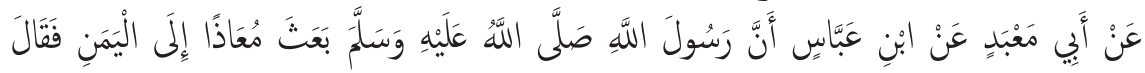

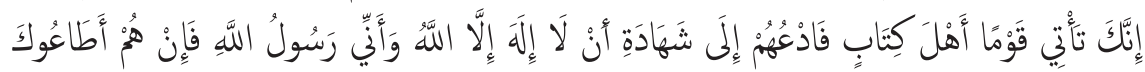

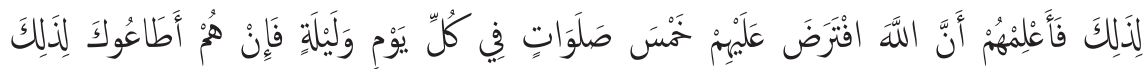

${ }^{29}$ Abu al-Husain Muslim bin al-Hajjaj al-Qusyairi, Shahih Muslim kitab iman hadis ke-27.

${ }^{30}$ Al-Turmuzi, op. cit., kitab zakat hadis ke-567

${ }^{31}$ Abu Abdurrahman Ahmad bin Syu'aib al-Nasai, Sunan al-Nasai dalam kitab al-zakat hadis ke-2392. 


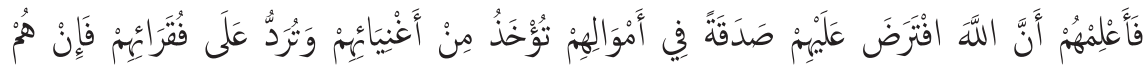

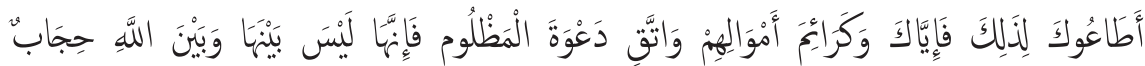

$$
{ }^{32} \text { (رواه أبوداودأس }
$$

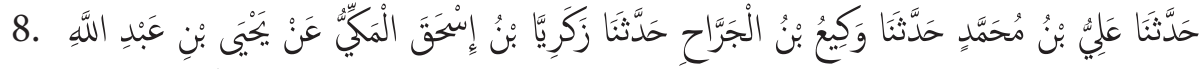

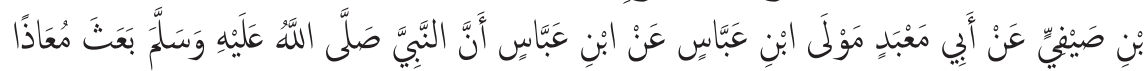

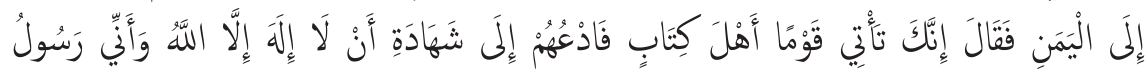

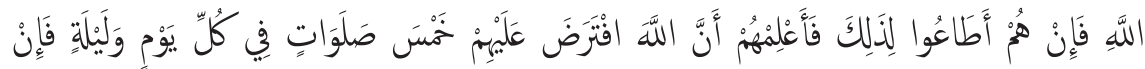

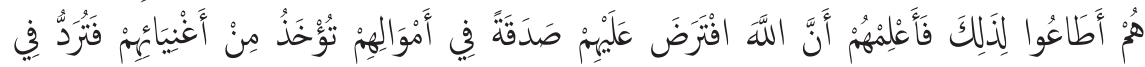

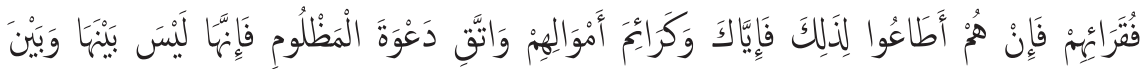

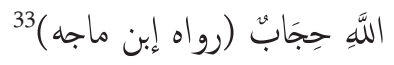

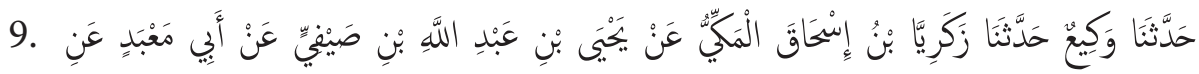

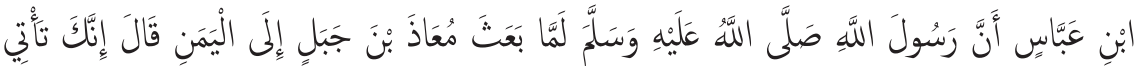

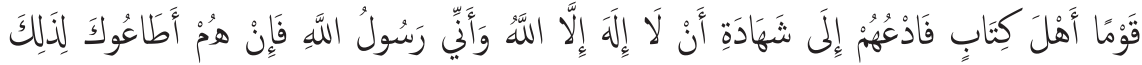

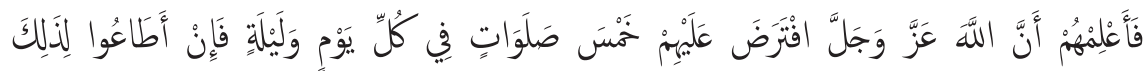

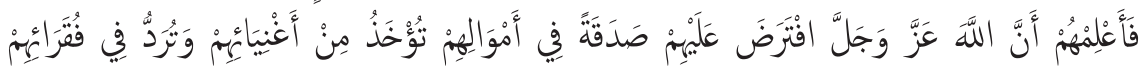

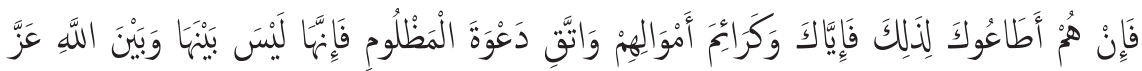

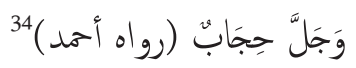

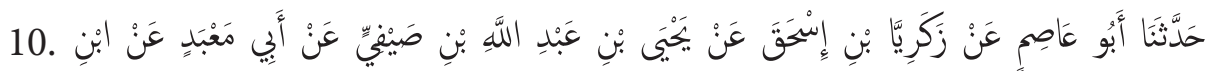

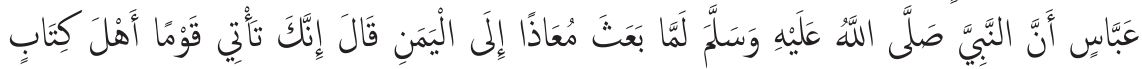

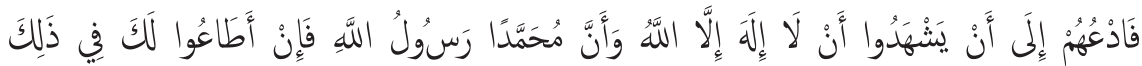

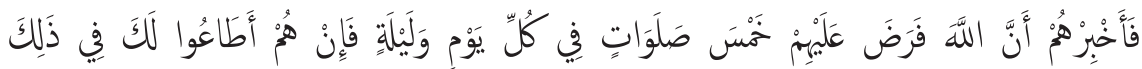

${ }^{32}$ Abu Dawud Sulaiman bin al-Asy'ats al-Sijistani, Sunan Abu Dawud kitab al-Zakat hadis ke-1351.

${ }^{33}$ Ibn Majah, op. cit., kitab al-zakat hadis ke-1773

${ }^{34}$ Abu Abdullah Ahmad bin Hanbal, Musnad Ahmad, dalam Musnad Baniy Hasyim hadis ke-1967. 


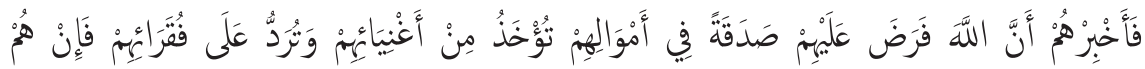

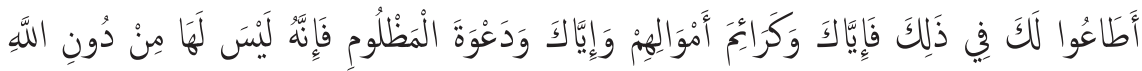
حِجَابُ (رواه الدارمي)

2. Hadis tentang nishab dan haul zakat mal

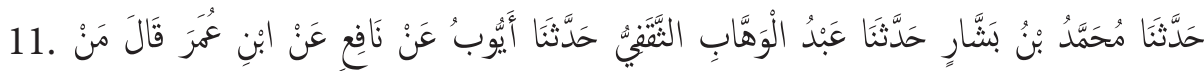

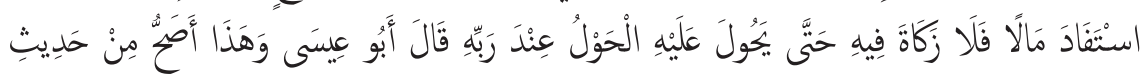

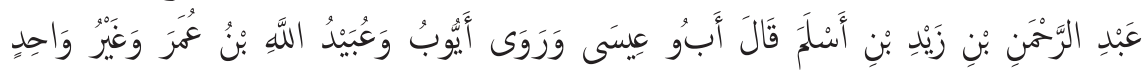

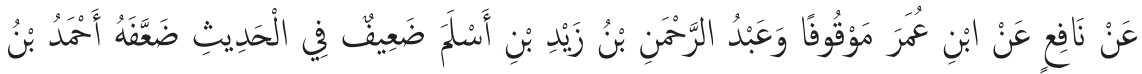

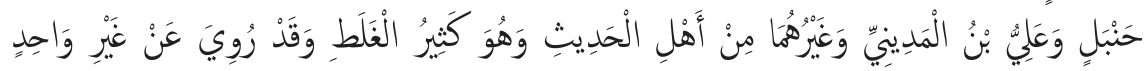

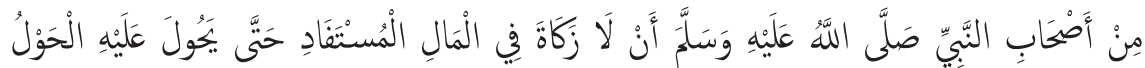

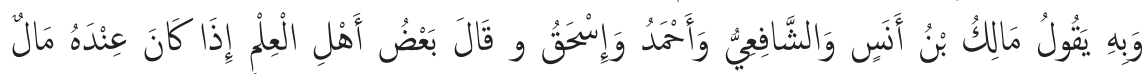

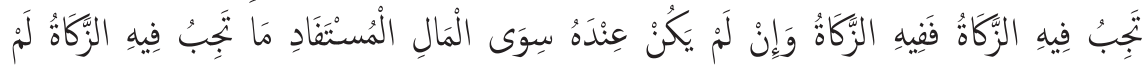

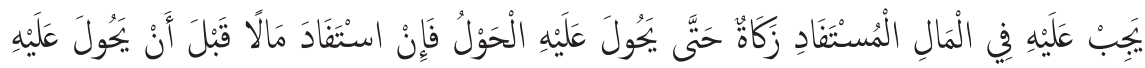

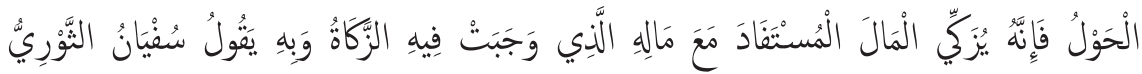

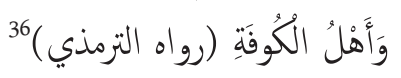

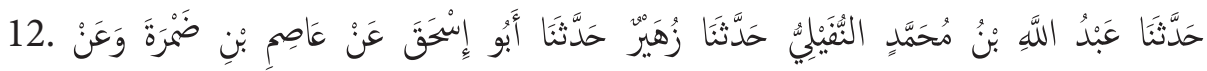

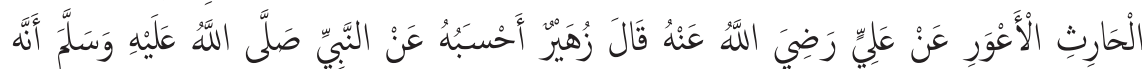

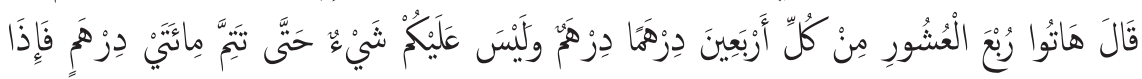

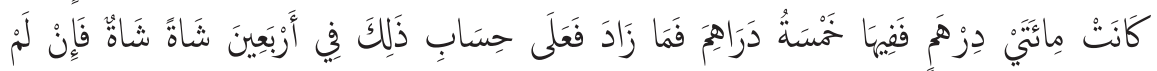

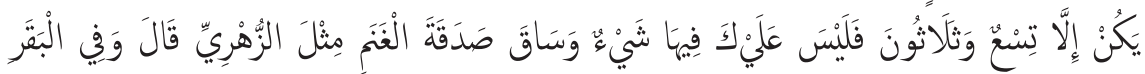

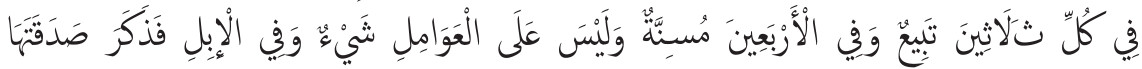

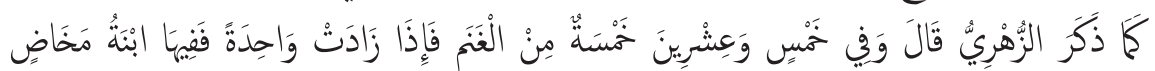

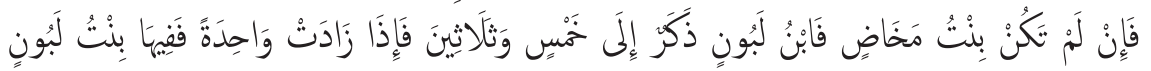

${ }^{35}$ Abu Muhammad bin Ahmad al-Darimiy, Sunan al-Darimiy, dalam kitab al-zakat hadis ke- 1563.

${ }^{36}$ Al-Turmuzi, op. cit., kitab al-zakat hadis ke-569. 


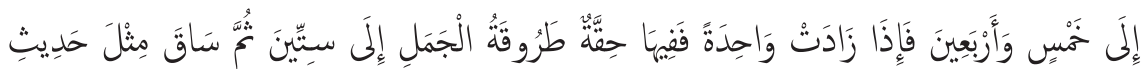

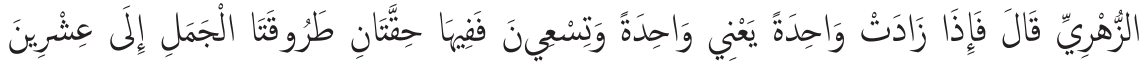

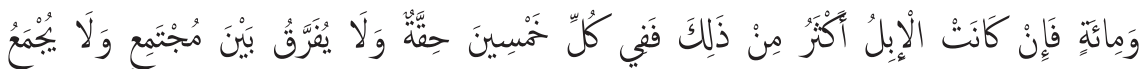

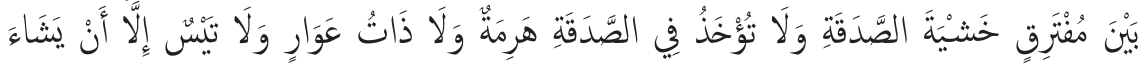

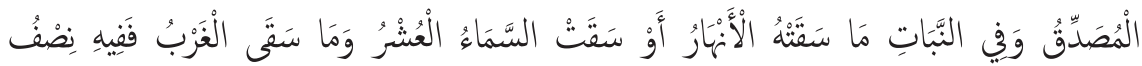

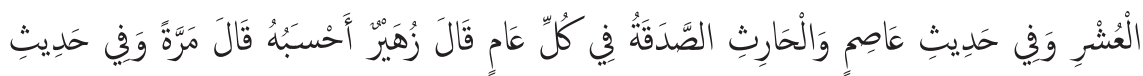

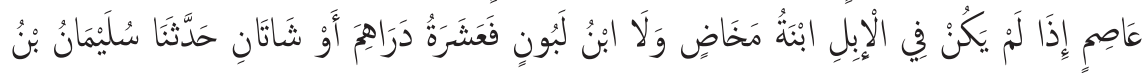

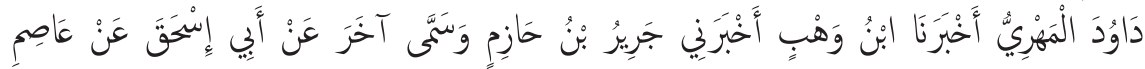

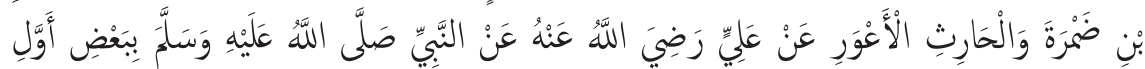

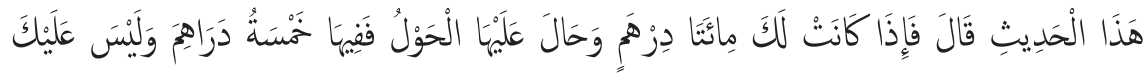

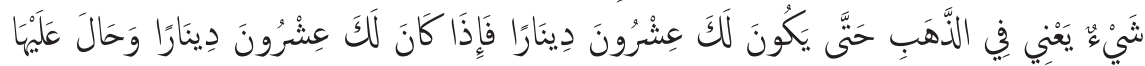

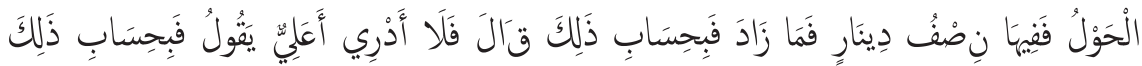

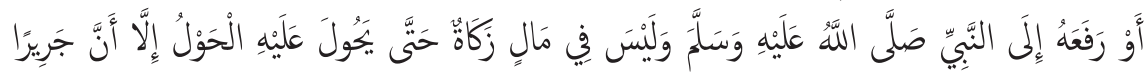

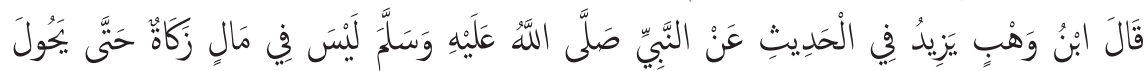

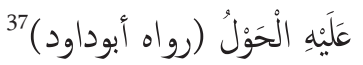

Dalam menentukan kualitas suatu hadis diperlukan kegiatan naqd al-sanad wa al-matan (kritik sanad dan matan), namun dalam kajian ini kualitas hadis tersebut didasarkan pada pendapat para kritikus hadis, dan analisis tentang-nya. Hadis tentang kewajiban zakat mal menurut al-Tumuziy berkualitas hasan garib. Hal ini sesuai pernyataannya sendiri bahwa :

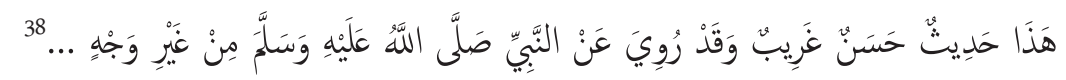

Artinya:

Hadis ini berkualitas hasan garib, dan telah diriwayatkan dari Nabi saw dari jalur sanad yang beragam.

\footnotetext{
${ }^{37}$ Abu Dawud, op. cit., kitab al-zakat hadis 1342.

${ }^{38}$ Al-Turmuziy, loc. cit.
} 
Kemudian dalam CD. Rom hadis dinyatakan bahwa hadits al-syarif marfu'un ilan Nabiy saw, ${ }^{39}$ (hadis ini sampai sanadnya pada Nabi saw). Perlu penulis tegaskan bahwa hadis hasan garib walaupun tidak sampai pada derajat shahih, bisa saja dijadikan hujjah (pegangan), dan apalagi bila ia marfu'u menandakan bahwa sanadnya disandarkan kepada Nabi saw. Penulis juga berpendapat bahwa hadis tentang kewajiban zakat ini bisa saja kualitasnya menjadi shahih apabila ia didukung oleh beberapa hadis yang semakna. Kaitannya dengan itu ditemukan pula hadis lain yang menerangkan tentang kewajiaban zakat. Hal ini dijumpai pada hadis-hadis yang juga telah dikutip yakni kewajiban muzakkiy mengeluarkan zakat mal yang antara lain dipahami dari bagian redaksinya

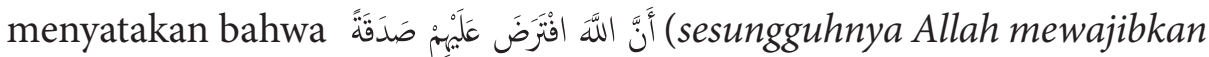
zakat kepada mereka). Hadis diriwayatkan oleh tujuh mukharrij dan di antaranya Bukhari dan Muslim sehingga kualitas hadis ini shahih. Karena hadis ini juga membicarakan tentang kewajiban zakat dengan kualitas yang shahih, maka ia dapat menunjang kualitas hadis kewajiban zakat mal diriwayatkan al-Tumuziy dan Ibn Majah tadi.

Mengenai hadis tentang haul dan nishab zakat yang diriwayatkan al-Tumuziy ditemukan data bahwa kualitasnya dhaif sebab ia mawquf. Demikian yang ditemukan dalam pernyataan al-Turmuzi sendiri, yakni " Tetapi ada juga ulama hadis yang menyatakan bahwa hadis dhaif dapat saja dijadikan selama untuk fadhail al-a'mal. ${ }^{41}$ Berdasar dari sini maka hadis tentang haul dan nishab yang diriwayatkan al-Turmuzi dapat diterima. Apalagi hadis yang semakna dengannya, yakni yang diriwayatkan Ibn Majah dapat dikatakan shahih karena tidak ulama yang men-dhaifkannya. Terlepas dari pemahaman tentang bagaimana kualitas hadis ini, apakah ia shahih atau tidak, yang jelaskanya para ulama fikih sependapat bahwa zakat mal ada nishab dan haulnya, dengan begitu hadis tersebut

\footnotetext{
${ }^{39}$ CD. Rom Hadis, dalam Barnabij al-Hadis al-Syarifah al-Kutub al-Tis'ah, program tadlil...

${ }^{40}$ Lihat pernyataan al-Turmuzi dalam hadis pada makalah ini, h. 11.

${ }^{41}$ Nur al-Din Itr, Ulum al-Hadits (Semarang: Toha Putra, 1989), h. 16.
} 
tetap saja dapat dijadikan pegangan untuk menentukan berapa nishab dan haul zakat mal.

\section{Analisis (Syarah) Hadis tentang Kewajiban Zakat Mal}

Kewajiban zakat mal yang dimaksud di sini berkaitan dengan dasar hukum disyariatkannya menunaikan zakat. Banyak sekali dalil-dalil tentang diwajibkannya zakat mal, dan dalil kewajiban tersebut perspektif hadis adalah diriwayatkan oleh al-Turmuzi dan Ibn Majah secara lafzhi yang matannya sebagai berikut :

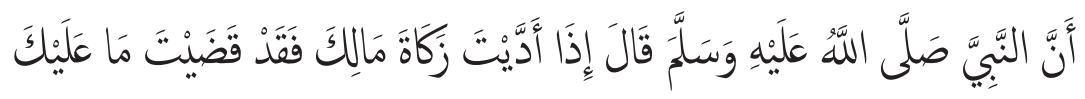

Artinya:

Adalah Nabi saw bersabda, apabila engkau telah mengeluarkan zakat harta-mu, maka engkau telah melaksanakan kewajibanmu

Matan hadis ini dimulai dengan huruf syartiy "إذَا" (apabila atau jika)

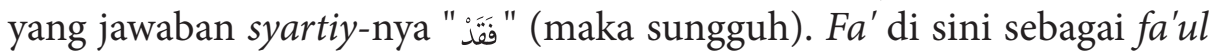
jawab dan qad sebagai ta'kid menandakan adanya "ketegasan" bahwa apabila zakat mal telah ditunaikan maka kewajiban telah dilaksanakan. Secara tegas hadis ini membicarakan zakat mal, bukan zakat fitrah, karena di dalam matannya kata zakat terangkai dengan kata 纪 dimana kata ini berasal dari kata mal (harta) dan dhamir "ka" menunjukkan kepunyaan misalnya " مَّ人 " مَإِكَ " artinya harta yang engkau miliki. Dalam kitab Tuhfatul Ahwaziy dijelaskan makna katakata dalam hadis tersebut secara tekstual sebagai berikut :

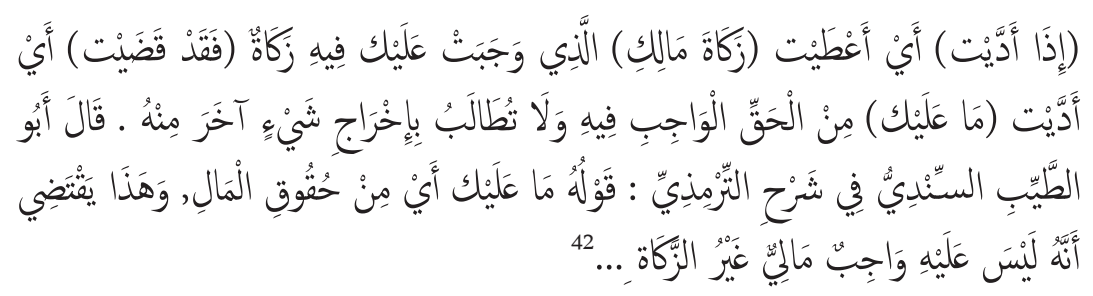

${ }^{42}$ Abu al-Ula Muhammaf bin Abdil Rahman al-Mubarakfuri, Tuhfatul Ahwaziy, juz III (Madinah Munawwarah: al-Maktabah al-Salafiyah, 1987), h. 121. 


\begin{abstract}
Artinya:
(Apabila engkau telah melaksanakan) yakni engkau telah memberikan (zakat hartamu) yang telah diwajibakan atasamu di antaranya adalah zakat (maka engkau telah menunaikan) atau engkau telah melaksanakan (apa kewajibanmu) dari hak atas harta itu dan engkau tidak dituntut mengeluar-kan hartamu pada selainnya kecuali zakat darinya. Dikatakannya Abu al-Thayyib alSindiy dalam syarah hadis al-Turmuziy bahwa perkatannya (Nabi saw) pada kalimat ma alaika mengandung arti hak-hak atas harta dan yang dikehendaki kalimat ini adalah bahwa pada harta itu tidak kewajiban kecuali padanya kewajiban zakat mal...
\end{abstract}

Berdasar dari kutipan di atas, dipahami bahwa pada setiap harta yang dimiliki di dalamnya ada kewajiban untuk mengeluarkan zakat dari harta yang dimiliki itu. Tentu saja yang diwajibkan di sini adalah semua harta yang tumbuh dan berkembang, karena makna dasar zakat adalah nabat (tumbuh). Harta yang tidak tumbuh dan berkembang seperti rumah tempat tinggal, perhiasan yang dipakai wanita, kendaraan yang dipakai semisal mobil, motor, sepeda dan semacamnya adalah tidak wajib zakat padanya. Kecuali bila rumah dan atau perhiasan tersebut disewakan, demikian pula bila mobil atau motor tersebut direntalkan dan menghasilkan harta, maka wajib padanya zakat.

Secara kontekstual hadis tersebut disebutkan sumber zakat mal yang sejak awal dipersiapkan untuk menghasilkan harta. Sedangkan sarana dan prasarana lain yang hanya dipakai untuk kebutuhan hidup individu semata dan atau untuk kepentingan pribadi, misalnya rumah hanya untuk ditinggali tidak dipersewakan, atau mobil untuk kebutuhan pribadi tidak direntalkan maka dengan sendirinya gugur kewajiban zakat padanya. Jadi bila semua fasilitas yang dimiliki di mana fasilitas tersebut memang diperuntukkan menghasilkan harta yang tumbuh dan berkembang, dan ada keuntungan bersih yang diperoleh darinya lalu dikeluarkan zakatnya sesuai ketentuan syariat setelah dihitung haul 
dan nishab-nya, ${ }^{43}$ maka dengan menunaikannya berarti yang bersangkutan telah melaksanakan kewajiban.

Dalam syariat Islam ditegaskan bahwa melaksanakan kewajiban mendapat pahala dan meninggalkan kewajiban mendapat dosa. Ini berarti bahwa mereka kikir dan yang enggan menunaikan zakat, maka telah melakukan dosa dan diberikan ganjaran yang sangat pedih di akhirat kelak. Allah swt berfirman dalam QS. Ali Imran (3): 180,

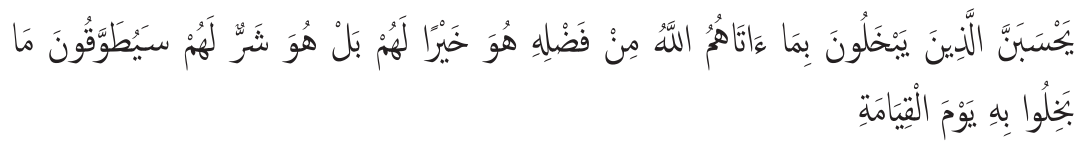

Artinya:

Sekali-kali janganlah orang-orang yang bakhil dengan harta yang Allah berikan kepada mereka dari karunia-Nya menyangka, bahwa kebakhilan itu baik bagi mereka. Sebenarnya kebakhilan itu adalah buruk bagi mereka. Harta yang mereka bakhilkan itu akan dikalungkan kelak di lehernya di hari kiamat. ${ }^{44}$

Ali Bassam kemudian menerangkan bahwa pahala zakat diberikan kepada orang Islam yang mengeluarkannya, sebab zakat tidak wajib bagi orang kafir, meskipun dia akan ditanya tentang zakat itu di akhirat dan dua akan diazab karena meninggalkan zakat. Zakat termasuk kebaikankebaikan Islam yang datang membawa persamaan hak, kasih sayang, tolong menolong dan memotong tiap jalan keburukan yang dapat mengancam keutamaan, keamanan, kelapangan dari berbagai sendi-sendiri kemaslahatan dunia dan akhirat. ${ }^{45}$

Kewajiban zakat ini sebagai perwujudan keimanan kepada Allah, mensyukuri nikmat-Nya, menumbuhkan akhlak mulia dengan rasa

\footnotetext{
${ }^{43}$ Hadis tentang haul dan nishab zakat mal akan dijelaskan pada uraian mendatang.

${ }^{44}$ Departemen Agama RI, Al-Qur'an dan Terjemahnya (Jakarta: Proyek Pengadaan Kitab Suci Al-Qur'an, 1992), h. 108.

${ }^{45}$ Abdullah bin Abdurrahman bin Shalih Ali Bassam, Taysir Allam Syahr Umdatul Ahkam, juz I (Makkah al-Mukarramah: Maktab wa Mathba'ah al-Nahdhah al-Haditsah, 1978), h. 386.
} 
kemanusiaan yang tinggi, menumbuhkan ketenangan hidup, menghilangkan sifat kikir, rakus dan materialistik atau mencintai harta secara berlebihan. ${ }^{46}$ Hidup materialistik sangat berbahaya. Arifuddin Ahmad menjelaskan dari sikap hidup materialistik itu, umat Islam akan berlomba-lomba di bidang kekayaan materi, kemudian pada gilirannya, umat Islam sebagaimana umat sebelumnya dilanda kehancuran. Itulah sebabnya, Nabi saw pada hakikat-nya tidak khawatir kemusyrikan akan melanda umat Islam, tetapi yang beliau khawatirkan adalah sikap hidup materialistis yang akan melanda umat Islam. ${ }^{47}$ Dengan kewajiban zakat pula memberikan jaminan bagi orang-orang lemah, fakir miskin untuk dapat mempertahankan hidupnya.

\section{Analisis (Syarah) Hadis tentang Muzakkiy dan Mustahiq Zakat Mal}

Muzakkiy artinya orang yang wajib mengeluarkan zakat, sedangkan mustahiq artinya orang yang wajib menerima zakat. Hadis tentangnya diriwayatkan oleh Bukhari, Muslim, al-Turmuzi, al-Nasai, Abu Dawud, Ahmad, dan al-Darimiy secara maknawiy. Dalam matan alBukhari dan al-Turmuzi redaksinya adalah :

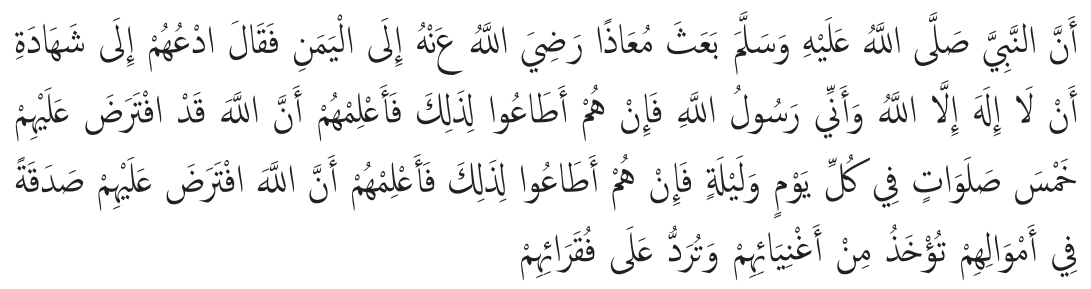

Artinya :

Nabi saw ketika mengutus Mu'az ra ke Yaman beliau bersabda: Ajaklah mereka (penduduk Yaman) untuk bersaksi tidak ada tuhan yang wajib di sembah kecuali Allah, dan aku (Nabi saw) adalah utusan Allah. Jika mereka telah taat beritahulah mereka bahwa Allah mewajibkan kepada mereka shalat lima waktu dalam sehari

\footnotetext{
${ }^{46}$ Didin Hafidhuddin, op. cit., 10

${ }^{47}$ Arifuddin Ahmad, op. cit., h. 230.
} 
semalam, jika mereka taat beritahu pula mereka bahwa Allah mewajibkan pada harta mereka zakat yang diambil dari orangorang kaya mereka dan diberikan kepada orang-orang fakir.

Sedangkan dalam matan Muslim, al-Nasai, Abu Dawud, Ahmad, dan al-Darimiy, redaksinya adalah :

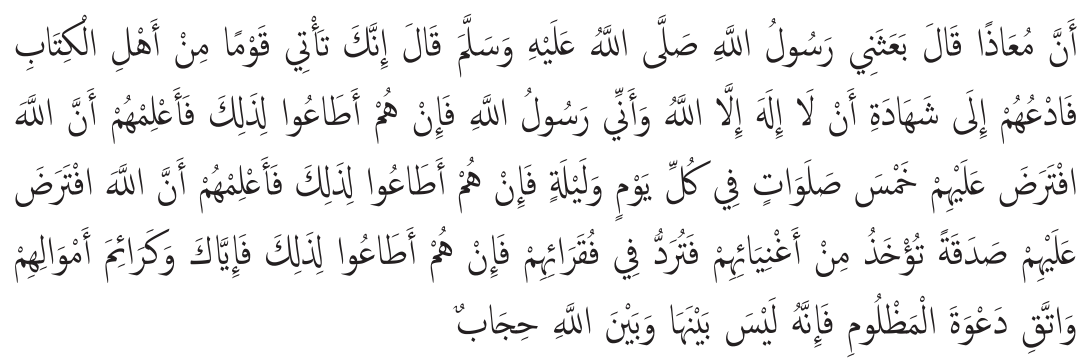

Artinya:

Adalah Mu'az bin jabal berkata, Rasulullah telah mengutusku ke Yaman dan bersabda: engkau akan mendatangi Ahli kitab, apabila engkau telah sampai pada mereka serulah supaya mereka mengucapkan kalimah syahadat. Jika mereka menerima kalimah syahadat tersebut sampaikanlah bahwa Allah telah telah memwajibkan mereka untuk mendirikan shalat limat waktu sehari semalam. Sekiranya mereka juga mentaati perintah tersebut, sampaikanlah bahwa Allah telah mewajibkan mengeluarkan zakat yang diambil dari orang-orang kaya di antara mereka untuk diberikan kepada yang fakir di antara mereka. Jika mereka tetap mentaatinya itu, maka hendaklah kamu (Mu'az) mengurus zakat harta mereka dan takutlah terhadap doa orang yang teraniaya karena doa mereka antara Tuhan tidak terhalang.

Memperhatikan dua hadis di atas redaksinya berbeda namun keduanya memiliki kandungan makna yang sama. Secara global kandungan hadis tersebut adalah bahwa muzakki adalah orang-orang kaya dan mustahiq adalah orang-orang fakir. Hadis ini menggunakan term shadaqah yang menunjuk pada arti zakat. Sabab wurud hadis ini adalah bahwa pada akhir tahun ke-9 H, Nabi saw membagi areal Yamal menjadi lima bagian denga lima orang delegasi sebagai penanggung jawabnya, yaitu 
Khalid bin Sa'id sebagai delegasi ke negeri bagian Shan'a. Al-Muhajir bin Umayya sebagai delegasi ke negeri bagian Kandah. Ziyad bin Abu Sa'd sebagai delegasi ke negeri bagian Hadramaut, Abu Musa al-Asy'ary sebagai delegasi ke negeri bagian Zabid, dan Mu'az yakni Mu'az bin Jabal sebagai delegasi ke negeri bagian al-Janad. Kelima orang tersebut diperintahkan oleh Nabi saw untuk memberikan arahan-arahan keagamaan, menyelesaian persengketaan di antara mereka, dan khusus kepada Mu'az ditambah lagi satu pesan dari Nabi saw sebagaimana dalam hadis, yakni Mu'az diperintahkan mengambil zakat dari $m u$ zakki dan untuk diberikan kepada mustahiq. ${ }^{48}$

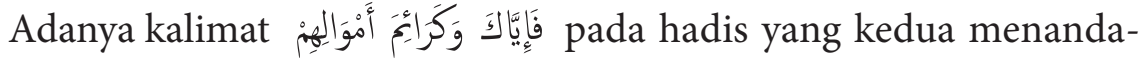
kan bahwa Nabi saw mengingatkan kepada Mu'az dan delegasi yang diutus agar tidak mengambil harta yang dianggap berharga bagi mereka seperti hewan yang sedang mengandung dan induk hewan yang sedang

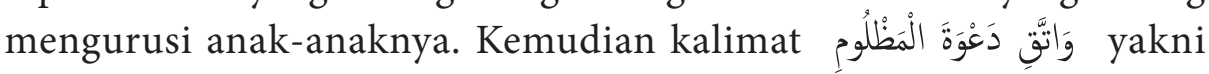
menghindari kezaliman agar orang yang dianiaya tidak mendoakan jelek bagimu, sebab doa orang yang teraniaya diterima oleh Allah meskipun orang tersebut fajir (suka berbuat dosa), sekalipun ia orang kafir sebab perbuatan dosanya merupakan tanggungjawab dirinya sendiri. ${ }^{49}$

Kalimat " صَدَقََ فِي أَمْوَالِهِمْ " dalam matan hadis diartikan zakat mal karena di sini ada kata amwalihin yang diambil dari orang-orang kaya yang

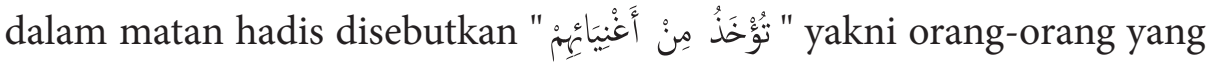
berlebih dari segi materi. Istilah kaya dalam terminologi Arab adalah, (orang yang banyak hartanya dia memiliki kemampuan), mereka inilah disebut muzakki yaitu orang kaya telah terpenuhi kebutuhan pokoknya dengan baik, dan dari zakat mereka diperuntukkan

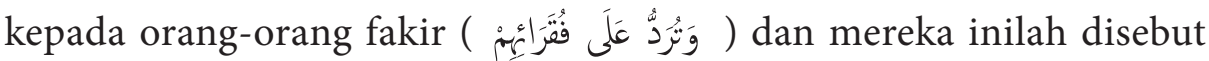
mustahiq.

${ }^{48}$ Abu al-Fadhl Ahmad bin Hajar al-Asqalani, Fathul Bary, juz II (Bairut: Maktabah al-Salafiyah, 1976), h. 62.

${ }^{49}$ Ibid., h. 63. Lihat juga Taufiq Rahman, Hadis-Hadis Hukum (Bandung: Pustaka Setia, 2000), h. 47.

${ }^{50}$ Luwis Ma'luf, op. cit., h. 561. 
Amat sulit memang untuk menentukan atau mengukur seseorang itu kaya dan atau apakah ia telah terpenuhi kebutuhan pokoknya atau belum, dan kebutuhan pokok setiap orang ternyata berbeda-beda, demikian pula dengan kebutuhan pokok antardaerah berbeda-beda. Karena itu, dua pendekatan yang bisa kita gunakan. Pertama, diserahkan pada kesadaran dan keikhlasan masing-masing muzakki untuk menghitung sendiri harta dan kebutuhan pokoknya secara wajar. Cara kedua menurut Didin Hafidhuddin adalah, dilakukan oleh Badan Amil Zakat (BAZ) atau Lembaga Amil Zakat (LAZ) untuk menentukan apakah seseorang itu termasuk kategori muzakki atau belum. ${ }^{51}$ Pendekatan pertama dan atau cara kedua ini sangat memungkinkan untuk dilakukan.

Kemudian mengenai mustahiq zakat menurut tekstual hadis yang dikaji ini hanya orang-orang fakir saja, namun semua imam mazhab memahami hadis tersebut secara kontekstual bahwa mustahiq zakat delapan kelompok, tetapi lebih diutamakan kelompok fakir terlebih dahulu. ${ }^{52}$ Allah swt berfirman dalam QS. al-Taubah (9): 60

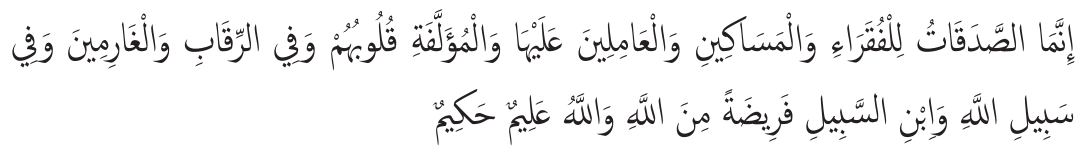

Artinya:

Sesungguhnya zakat-zakat itu, hanyalah untuk orang-orang fakir, orang-orang miskin, pengurus-pengurus zakat, para mu'allaf yang dibujuk hatinya, untuk (memerdekakan) budak, orang-orang yang berhutang, untuk jalan Allah dan orang-orang yang sedang dalam perjalanan, sebagai sesuatu ketetapan yang diwajibkan Allah; dan Allah Maha Mengetahui lagi Maha Bijaksana. ${ }^{53}$

${ }^{51}$ Didin Hafidhuddin, op. cit., h. 27.

${ }^{52}$ Muhammad Jawad Mugniyah, Al-Fiqh 'Ala al-Mazahib al-Khamsah diterjemahkan oleh Masykur A.B, Fif Muhammad, dan Idrus al-Kaff dengan judul Fiqih Lima Mazhab; Ja'fari, Maliki, Syafi, Hanbali (Cet. II; Jakarta: Lentera, 1996), h. 189.

${ }^{53}$ Departemen Agama RI, Al-Qur'an dan Terjemahnya op. cit., h. 288. 
Delapan kelompok asnaf sebagai mustahiq zakat dalam ayat ini adalah:

1. Fakir, yaitu orang yang tidak berharta dan tidak mempunyai pekerjaan atau usaha tetap guna mencukupi kebutuhan hidupnya (nafkah) sedangkan orang yang menanggung atau menjamin tidak ada.

2. Miskin, yaitu orang-orang yang tidak mencukupi kebutuhan hidupnya, meskipun ia mempunyai pekerjaan atau usaha tetap, tetapi hasil usaha itu belum dapat mencukupi kebutuhannya, dan orang yang menanggung atau menjamin juga tidak ada.

3. Amil, yaitu orang atau panitia atau organisasi yang mengurusi zakat, baik mengumpul, membagi, atau mendaya gunakan. Amil yang dimaksud di sini misalnya pengurus BAZ.

4. Muallaf, yaitu orang yang masih lemah imannya, karena baru memeluk agama Islam, tetapi masih lemah dalam arti masih ragu-ragu kemauannya untuk memeluk Islam.

5. Riqab, yaitu hamba sahaya yang mempunyai perjanjian akan dimerdekakan oleh majikannya dengan menebus dengan uang, tapi yang bersangkutan belum memiliki uang.

6. Gharim, yaitu orang yang mempunyai hutang karena suatu kepentingan yang bukan maksiat dan mampu melunasinya.

7. Sabilillah, yaitu usaha-usaha yang tujuannya untuk meningkatkan syiar agama Islam seperti membela dan mempertahankan agama, mendirikan tempat ibadah, pendidikan, dan lembagalembaga keagamaan lainnya.

8. Ibn Sabil, yaitu orang yang kehabisan bekal dalam bepergian dengan maksud baik, misalnya menuntut ilmu di perantauan.

Walaupun para ulama mazhab telah bersepakat bahwa terdapat delapan orang wajib menerima zakat sesuai petunjuk ayat tadi, dan mereka juga sependapat bahwa harus diutamakan orang fakir sebagaimana hadis yang dikaji, namun lebih lanjut Abu Hanifah, Ahmad, dan para pengikut Hanifah berpendapat bahwa pembagian zakat itu, apa- 
bila memungkinan, dianjurkan untuk dialokasikan secara menyeluruh kepada para mustahiq dan boleh juga dialokasikan kepada sebagian mustahiq meskipun hanya seorang, yakni orang fakir. Imam Malik berpendapat bahwa zakat itu hendaknya diberikan kepada orang yang lebih membutuhkan dan tidak mesti menyeluruh kepada semua mustahiq. Imam al-Syafii berpendapat zakat hendaknya dialokasikan secara menyeluruh apabila imam/pemerintah yang membagikannya. ${ }^{54}$

Nabi saw dalam hadis yang tadi memang hanya menyebut satu golongan mustahiq zakat, yakni orang-orang fakir di antara mereka (فُشَرَأَهْن ), orang yang tidak memiliki pekerjaan, atau dia memiliki harta benda dan pekerjaan tetapi harta dan pekerjaannya itu tidak mampu mencukupi untuk memenuhi kebutuhannya. Misalnya orang yang membutuhkan sepuluh macam kebutuhan, tetapi dia hanya memiliki dua macam kebutuhan. Dalam hal ini, zakat diperuntukkan secara khusus bagi orang-orang fakir, tanpa menyebut para mustahiq lainnya dalam hadis tersebut karena keadaan seperti itulah yang terjadi di zaman Nabi saw. Jadi hadis ini ketika disabdakan mentakhsis QS. al-Taubah (9): 60, dan itu terjadi di zaman Nabi saw. Untuk zaman sekarang, hadis tersebut masih perlu dikontekstualkan dengan memilah delapan mustahiq, atau dengan cara mengakomodir delapan mustahiq sesuai dengan keadaan kondisi zaman sekarang.

\section{Analisis (Syarah) Hadis tentang Nishab dan Haul Zakat Mal}

Nishab adalah kadar kuantiatas harta yang wajib dikeluarkan zakatnya, sedangkan haul adalah kadar batas waktu tertentu bagi harta untuk dikeluarkan zakatnya. Hadis yang terkait dengan ini diriwayatkan oleh al-Turmuzi dan Abu Dawud secara maknawi. Bagian inti redaksi hadis yang diriwayatkan al-Tumuzi adalah,

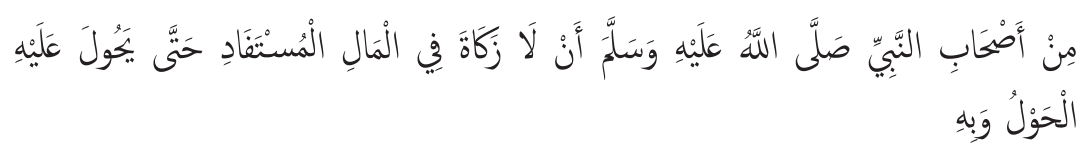

\footnotetext{
${ }^{54}$ Taufiq Rahman, op. cit., h. 51.
} 
Artinya:

Riwayat dari sahabat-sahabat Nabi saw bahwa tidak wajib zakat pada harta yang dihasilkan kecuali sampai pada batas waktu yang telah ditentukan waktu atasnya. ${ }^{55}$

Kemudian bagian-bagian penting redaksi hadis Abu Dawud adalah:

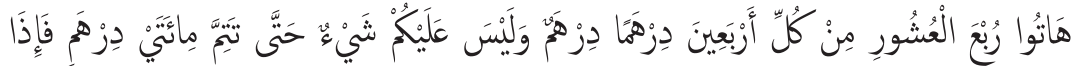

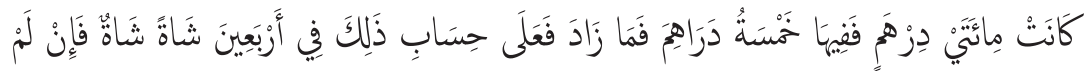

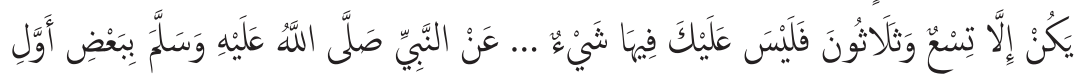

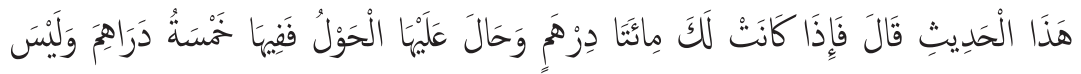

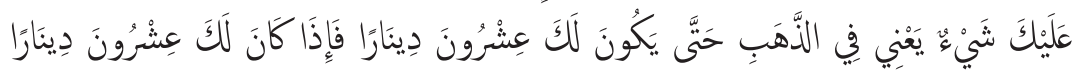

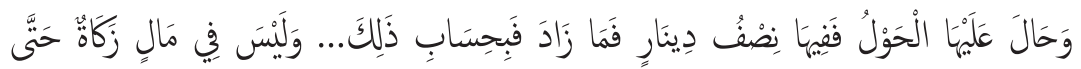

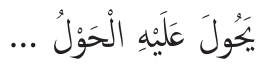

Artinya:

Tetapkan nishab pada mereka 4/20 pada tiap 40 dirham, dan tidak dibebankan atas kalian zakat hingga mencapai 200 dirham, apabila mencapai 200 dirham di dalamnya zakat tidak lebih 5 dirham demikian juga atas hitungan 40 ekor kambing zakatnya seekor kambing dan bila mencapai misalnya hanya 39 maka tidak ada zakat bagimu atasnya...dari Nabi saw pada redaksi awal hadis ini beliau bersabda: Apabila ada bagimu 200 dirham dan lewat atasnya satu tahun, maka zakat padanya lima dirham, dan tidak wajib atasmu zakat untuk perak hingga mencapai 20 dirham, apabila engkau memiliki 20 dinar dan sampai batasnya satu tahun setelah dihitung maka zakatnya tidak lebih setengah dinar menurut perhitungannya.... dan tidak ada di satu harta zakat hingga lewat atasnya satu tahun...

${ }^{55}$ Taufiq Rahman, op. cit., h. 51. 
Tabel 1

Nishab dan Haul Zakat Unta

\begin{tabular}{|c|c|l|}
\hline No. & $\begin{array}{c}\text { Nishab } \\
\text { (Ekor) }\end{array}$ & \multicolumn{1}{|c|}{ Kadar Haul Zakat } \\
\hline 1 & $5-9$ & $\begin{array}{l}1 \text { ekor kambing berumur 2 tahun atau lebih atau } \\
\text { domba berumur 1 tahun atau lebih }\end{array}$ \\
\hline 2 & $10-14$ & $\begin{array}{l}\text { 2 ekor kambing berumur 2 tahun atau lebih atau } \\
\text { domba berumur 1 tahun atau lebih }\end{array}$ \\
\hline 3 & $15-19$ & $\begin{array}{l}\text { 3 ekor kambing berumur 2 tahun atau lebih atau } \\
\text { domba berumur 1 tahun lebih }\end{array}$ \\
\hline 4 & $20-24$ & $\begin{array}{l}4 \text { ekor kambing berumur 2 tahun atau lebih atau } \\
\text { domba berumur 1 tahun atau lebih }\end{array}$ \\
\hline 5 & $25-35$ & $\begin{array}{l}1 \text { ekor unta betima umur 1 tahun memasuki } \\
\text { tahun ke-2 }\end{array}$ \\
\hline 6 & $36-45$ & $\begin{array}{l}1 \text { ekor unta betima umur 2 tahun memasuki } \\
\text { tahun ke-3 }\end{array}$ \\
\hline 7 & $46-60$ & $\begin{array}{l}1 \text { ekor unta betima umur 3 tahun memasuki } \\
\text { tahun ke-4 }\end{array}$ \\
\hline 8 & $61-75$ & $\begin{array}{l}1 \text { ekor unta betima umur } 4 \text { tahun memasuki } \\
\text { tahun ke-5 }\end{array}$ \\
\hline 9 & $76-90$ & $\begin{array}{l}\text { 2 ekor unta betima umur 2 tahun memasuki } \\
\text { tahun ke-3 }\end{array}$ \\
\hline 10 & $91-120$ & $\begin{array}{l}\text { 2 ekor unta betima umur 3 tahun memasuki } \\
\text { tahun ke-4 }\end{array}$ \\
\hline
\end{tabular}

Selanjutnya, jika setiap jumlah itu bertambah 40 ekor, maka zakatnya bertambah 1 ekor unta betina umur 2 taun memasuki tahun ke-3. apabila jumlah itu bertambah 50 ekor, maka zakatnya bertamba 1 ekor unta betina umur 3 tahun memasuki 4 tahun. Nishab kerbau dan kuda disetarakan (qiyas) dengan nishab sapi, yakni sebanyak 30 ekor. Apabila seseorang telah memiliki 30 ekor sapi, kerbau, atau kuda, maka ia wajib mengeluaran zakatnya. ${ }^{56}$ Secara rinci mengenai nishab dan kadar zakat sapi kerbau, atau kuda, dapat dilihat pada tabel berikut:

\footnotetext{
${ }^{56}$ Ibid., h. 26.
} 
Tabel 2

Nishab dan Haul Zakat Sapi

\begin{tabular}{|c|c|l|}
\hline No. & $\begin{array}{c}\text { Nishab } \\
\text { (Ekor) }\end{array}$ & \multicolumn{1}{|c|}{ Kadar Haul Zakat } \\
\hline 1 & $30-39$ & $\begin{array}{l}1 \text { ekor sapi jantan/betina umur 1 tahun memasuki tahun } \\
\text { ke-2 }\end{array}$ \\
\hline 2 & $40-59$ & 1 ekor sapi betina umur 2 tahun memasuki tahun ke-3 \\
\hline 3 & $60-69$ & 2 ekor sapi umur 1 tahun memasuki tahun ke-2 \\
\hline 4 & $70-79$ & $\begin{array}{l}\text { 1 ekor sapi umur 2 tahun memasuki tahun ke-3 dan } \\
1 \text { ekor sapi umur 1 tahun memasuki tahun ke-2 }\end{array}$ \\
\hline 5 & $80-89$ & 1 ekor sapi umur 2 tahun memasuki tahun ke-3 \\
\hline
\end{tabular}

Selanjutnya, jika setiap jumlah itu bertambah 30 ekor, maka zakatnya bertambah 1 ekor sapi umur 1 tahun memasuki tahun ke-2. Apabila jumlah itu bertambah 40 ekor, maka zakatnya bertambah 1 ekor sapi umur 2 tahun memasuki tahun ke-3. Nishab kambing atau domba adalah sebanyak 40 ekor. Apabila seseorang telah memiliki 40 ekor kambing atau domba, maka ia telah wajib mengeluarkan zakatnya. ${ }^{57}$ Secara rinci mengenai nishab dan kadar zakat kambing atau domba ini dapat dilihat pada tabel berikut:

Tabel 3

Nishab dan Haul Zakat Kabing/Domba

\begin{tabular}{|c|c|l|}
\hline No. & $\begin{array}{c}\text { Nishab } \\
\text { (Ekor) }\end{array}$ & \multicolumn{1}{c|}{ Kadar Haul Zakat } \\
\hline 1 & $40-120$ & $\begin{array}{l}\text { 1 ekor kambing umur 2 tahun atau domba umur } \\
1 \text { tahun }\end{array}$ \\
\hline 2 & $121-200$ & 2 ekor kambing atau domba \\
\hline 3 & $201-300$ & 2 ekor kambing atau domba \\
\hline
\end{tabular}

\footnotetext{
${ }^{57}$ Ibid., h. 27.
} 
Selanjutnya, setiap jumlah itu bertambah 100 ekor, maka zakatnya bertambah 1 ekor. Nishab pada ternak unggas dan perikanan tidak ditentukan kadar jumlah ternaknya pasti sebagaimana dalam ternak unta, sapi, dan kambing. Nishab pada ternak unggas dan perikanan ditentukan dengan nilai sebesar 20 dinar atau 85 gram emas. Apabila seorang peternak unggas dan perikanan di akhir tahun (tutup buku) memiliki jumlah ternak senilai 85 gram emas, maka peternak itu telah wajib mengeluarkan zakat sebesar $2,5 \%$.

\section{a. Emas dan Perak.}

Nishab kewajiban mengeluarkan zakat emas adalah 20 dinar atau 80 gram murni (1 dinar sama dengan 4,25 gram emas murni) dan zakat perak adalah 200 diram atau setara dengan 672 gram perak. Apabila se-seorang telah memiliki emas seberat 85 gram atau memiliki perak seberat 672 gram, maka telah wajib mengeluarkan zakat sebesar 2,5\%. ${ }^{58}$ Selain emas murni dan perak, harta simpanan lain yang dapat di-qiyaskan pada keduanya, seperti uang tunai, tabungan, cek, saham, surat berharga, atau bentuk lainnya, bila jumlahnya telah senilai dengan nishab emas dan perak, maka wajib dikeluarkan zakatnya sebesarnya $2,5 \%$ setiap tahun.

\section{b. Harta Perniagaan dan Perusahaan.}

Harta dari hasil perniagaan melalui perdagangan, industri, jasa, dan sejenisnya bila telah sampai pada nishab wajib pula untuk dizakati. Nishab dari harta hasil perniagaaan ini di-qiyas-kan pada nishab emas, yakni 85 gram sebesar 2,5\%. Apabila sebuah perniagaan pada akhir tahun atau tutup buku telah memiliki harta kekayaan (modal dan keuntungan) senilai 85 gram, maka perniagaan itu telah wajib untuk mengeluarkan zakat sebesar 2,5\% dari seluruh harta perniagaannya. ${ }^{59}$

${ }^{58}$ Ibid., h. 28. Lihat juga Imam Taqiy al-Din Abu Bakar Muhammad al-Husainiy al-Hushniy al-Dimasyqi al-Syafí'iy, op. cit., h. 176.

${ }^{59}$ Sayyid Sabiq., ibid., h. 29. Lihat juga Imam Taqiy al-Din Abu Bakar Muhammad al-Husainiy al-Hushniy al-Dimasyqi al-Syafī'iy, op. cit., h. 177. 
Apabila perniagaan itu berupa musyārakah (kerjasama/koperasi) dari beberapa orang, maka sebelum harta perniagaan itu dibagikan kepada masing-masing sesuai dengan porsinya, harta perniagaan itu wajib terlebih dahulu dikeluarkan zakatnya. Ketentuan ini berlaku apabila pihak-pihak yang berserikat itu semuanya beragama Islam. Tetapi, bila dalam musyärakah itu terdapat non muslim, maka zakat hanya dikeluarkan dari harta perniagaan yang menjadi hak musyārik yang muslim.

\section{c. Hasil Pertanian}

Nishab hasil pertanian adalah 5 washq atau setara dengan $750 \mathrm{~kg}$. Namun kadar yang harus dikeluarkan dalam menunaikan zakatnya terbagi kepada dua bagian, yaitu pertama apabila pertanian itu diairi dengan air hujang atau sungai, maka zakat yang harus dikeluarkannya sebesar $10 \%$, kedua apabila pertanian itu diairi dengan cara disiram, maka zakat yang harus dikeluarkannya sebesar $5 \%{ }^{60}$

Penghasilan-penghasilan lain selain dari yang telah kemukakan di atas, nishab dan kadar zakatnya dapat dianalogikan (di-qiyas-kan) kepada ketentuan yang telah pasti yang termuat dalam Alquran dan hadis, seperti pendapatan dari jasa, pertambangan, dan rikaz.

Sekarang ini, lagi ramai dibicarakan tentang zakat profesi, atau zakat penghasilan dan pendapatan melalui keahlian, misalnya profesi dokter, arsitek, pengacara, guru, dosen dan semacamnya. Kaitannya dengan ini, terdapat beberapa kemungkinan dalam menentukan nishab dan haul atau waktu mengeluarkan zakat profesi. Hal ini tergantung pada qiyas yang dilakukan. Misalnya, jika di-qiyas-kan pada zakat perdagangan, maka nishab dan kadar haul mengeluarkannya sama dengannya dan sama dengan zakat emas dan perak. Nishabnya senilai 85 gram emas dengan jumlah zakat 2,5\% dan haulnya setahun sekali, setelah dikurangi kebutuhan pokok. Contoh, si A berpenghasilan 5.000.000,00 setiap bulan dan kebutuhan pokok perbulannya 3.000.000, 00 maka besar zakat yang dikeluarkan adalah 2,5\% x 12 x Rp.200.000,00 atau

\footnotetext{
${ }^{60}$ Sayyid Sabiq., ibid., h. 30.
} 
sebesar Rp. 600.000/tahun atau Rp. 50.000,00/bulan. Namun bila zakat profesi di-qiyas-kan pada zakat pertanian, maka tidak ada ketentuan haul. Ketentuan waktu menyalurkannya adalah pada saat menerima, yaitu setelah gajian.

\section{Penutup}

Zakat terdiri atas dua macam, zakat fitrah dan zakat mal. Yang menjadi kajian penulis di sini adalah zakat mal yakni zakat harta yang dikeluarkan apabila telah cukup nishab dan haulnya dibebankan kepada setiap muslim yang kaya. Yang termasuk zakat mal adalah zakat peternakan, zakat emas dan perak, zakat hasil perniagaan, dan zakat hasil pertanian, dan termasuk zakat profesi. Hadis-hadis tentang zakat mal diketahui setelah melakukan takhrij, dan dari sini kemudian diketahui kualitas hadis-hadis tersebut. Dari hasil takhrij pula dijelaskan (syarah) tiga tema hadis. Pertama, hadis tentang kewajiban zakat mal yang menegaskan bahwa apabila zakat mal telah ditunaikan maka kewajiban telah dilaksanakan. Semua harta benda (mal) yang tumbuh dan berkembang wajib dikeluarkan zakatnya sebagai tanda pensucian harta dan menghindarkan seseorang untuk bergelimang dalam dunia materialis. Kedua, kewajiban zakat dibebankan kepada muzakki yang tergolong kaya, berkecukupan dalam memenuhi kebutuhan hidupnya, dan zakat tersebut diperuntukkan lebih utama dan lebih awal kepada orang-orang fakir, kemudian menyusul kepada orang-orang miskin, amil, mu'allaf, hamba sahaya yang ingin merdeka, orang yang dililit hutang, yang berada di sabilillah, dan ibn sabil. Ketiga, setiap zakat mal yang dikeluarkan ada nishab dan haulnya. Nishab adalah kadar kuantitas harta dan haul adalah kadar batas waktu tertentu bagi harta untuk dikeluarkan zakatnya. Termasuk zakat profesi untuk zaman sekarang nishab dan haulnya bisa di-qiyas-kan (dianalogikan) kepada ketentuan zakat mal lainnnya yang telah ada nasnya dalam dalam al-Quran dan hadis.

Berdasar pada kesimpulan di atas, maka implikasi akhir dari pembahasan ini adalah masih penting dikaji ulang konsep zakat mal 
perspektif hadis sebagai mana yang telah dipaparkan dalam makalah. Untuk tujuan tersebut, maka disarankan agar diskusi tentangya sangat diharapkan demi kesempurnaan pembahasan. Di samping itu tentunya, saran dan kritik dari berbagai pihak sangat dibutuhkan untuk lebih akurat dan komprehensipnya pembahasan ini.

\section{Daitar Pustaka}

\section{Al-Qur'an al-Karim}

Ahmad, Arifuddin. Paradigma Baru Memahami Hadis Nabi; Refleksi Pemikiran Prof. Dr. M. Syuhudi Ismail. Cet.I; Jakarti: Renaisan, 2005.

Al-Asqalani, Abu al-Fadhl Ahmad bin Hajar. Fathul Bary, juz II. Bairut: Maktabah al-Salafiyah, 1976.

Al-Baqy, Muhammad Fu'ad Abd. Al-Mu'jam al-Mufahras Li Alfazh alQur'an al-Karim. Bairut: Dar al-Fikr, 1992.

Bassam, Abdullah bin abdurrahman bin Shalih Ali. Taysir Allam Syahr Umdatul Ahkam, juz I. Cet. V; Makkah al-Mukarramah: Maktab wa Mathba'ah al-Nahdhah al-Haditsah, 1978.

Al-Bukhari, Abu Abdullah Muhammad bin Ismail bin al-Mughirah bin al-Bardizbah. Shahih Bukhari dalam Program CD. Rom Hadis alSyarif.

Al-Darimiy, Abu Muhammad bin Ahmad. Sunan al-Darimiy, dalam Program CD. Rom Hadis al-Syarif.

Departemen Agama RI, Al-Qur'an dan Terjemahnya. Jakarta: Proyek Pengadaan Kitab Suci Al-Qur'an, 1992.

Hafidhuddin, Didin. Zakat dalam Perekonomian Modern. Cet. I; Jakarta: Gema Insani Press, 2002.

Al-Hushniy al-Dimasyqi al-Syafí'iy, Imam Taqiy al-Din Abu Bakar 
Muhammad al-Husainiy. Kifayat al-Akhyar fi Hali Ghayat alIkhtishar, juz I. t.t, : Syirkah al-Ma'arif li al-Thab'i wa al-Nasyr, t.th.

Ibn Hanbal, Abu Abdullah Ahmad. Musnad Ahmad, dalam Program CD. Rom Hadis al-Syarif.

Ibn Majah, Abdullah Muhammad bin Yazid. Sunan Ibn Majah, dalam Program CD. Rom Hadis al-Syarif.

Itr, Nur al-Din. Ulum al-Hadits. Semarang: Toha Putra, 1989.

Ma'luf, Luwis. al-Munjid fyy al-Lugah. Bairut: Dar al-Masyriq, 1977.

Al-Maududi, Abu 'A’la. Dasar-dasar Ekonomi Islam "terjemahan” oleh Abdul.ah Suhaili. Bandung: PT. al-Ma’arif, 1980.

M. Syuhudi Ismail, Metodologi Penelitian Hadis. Cet. I; Jakarta: Bulan Bintang, 1992.

Al-Mubarakfuri, Abu al-Ula Muhammaf bin Abdil Rahman. Tuhfatul Ahwaziy, juz III. Madinah Munawwarah: al-Maktabah al-Salafiyah, 1987.

Mugniyah, Muhammad Jawad. Al-Fiqh 'Ala al-Mazahib al-Khamsah diterjemahkan oleh Masykur A.B, Fif Muhammad, dan Idrus al-Kaff dengan judul Fiqih Lima Mazhab; Ja'fari, Maliki, Syafi, Hanbali. Cet. II; Jakarta: Lentera, 1996.

Al-Nasai, Abu Abdurrahman Ahmad bin Syu'aib. Sunan al-Nasai dalam Program CD. Rom Hadis al-Syarif.

Al-Qardhawi, Yusuf. Fiqh al-Zakat diterjemahkan oleh Salman Harun, Didin Hafidhuddin, dan Hasanuddin dengan Hukum Zakat. Cet. IV; Jakarta: Pustaka Lentera AntarNusa, 1996.

Al-Qusyairi, Abu al-Husain Muslim bin al-Hajjaj. Shahih Muslim dalam Program CD. Rom Hadis al-Syarif.

Rahman, Taufiq. Hadis-Hadis Hukum. Bandung: Pustaka Setia, 2000.

Sabiq, Sayyid. Fiqh al-Sunnah, jilid III. Cet. VIII: Bairut: Dār al-Kitāb al'Arabiya, 1987. 
Shihab, M. Quraish. Fatwa-fatwa Seputar Ibadah Mahdah. Cet. I; Bandung: Mizan, 1999. . Tafsir al-Mishbah; Pesan, Kesan dan Keserasian Al-Qur'an, vol. 5. Cet. V; Jakarta: Lentera Hati, 2006.

Al-Sijistani, Abu Dawud Sulaiman bin al-Asy'ats. Sunan Abu Dawud dalam Program CD. Rom Hadis al-Syarif.

Al-Turmuziy, Abu Isa Muhammad ibn Isa ibn Sawrah. Sunan al-Turmuziy, dalam Program CD. Rom Hadis al-Syarif.

Wensinck, Arnold John et al, Concordance et Indices De Ela Tradition Musulmanne, diterjemahkan ke dalam bahasa Arab oleh Muhammad Fu'ad 'Abd. al-Baqy dengan judul al-Mu'jam alMufahras Li Alfazh al-Hadits al-Nabawy, juz II-IV. Leiden: E. J.Brill, 1936. 